\title{
Poaceae Pollen from Southern Brazil: Distinguishing Grasslands (Campos) from Forests by Analyzing a Diverse Range of Poaceae Species
}

\author{
Jefferson N. Radaeski ${ }^{1,2}$, Soraia G. Bauermann ${ }^{2 *}$ and Antonio B. Pereira ${ }^{1}$ \\ ${ }^{1}$ Universidade Federal do Pampa, São Gabriel, Brazil, ${ }^{2}$ Laboratório de Palinologia da Universidade Luterana do \\ Brasil-ULBRA, Universidade Luterana do Brazil, Canoas, Brazil
}

This aim of this study was to distinguish grasslands from forests in southern Brazil by analyzing Poaceae pollen grains. Through light microscopy analysis, we measured the size of the pollen grain, pore, and annulus from 68 species of Rio Grande do Sul. Measurements were recorded of 10 forest species and 58 grassland species, representing all tribes of the Poaceae in Rio Grande do Sul. We measured the polar, equatorial, pore, and annulus diameter. Results of statistical tests showed that arboreous forest species have larger pollen grain sizes than grassland and herbaceous forest species, and in particular there are strongly significant differences between arboreous

OPEN ACCESS

Edited by:

Encarni Montoya,

Institute of Earth Sciences Jaume Almera (CSIC), Spain

Reviewed by:

José Tasso Felix Guimarães, Vale Institute of Technology, Brazil Lisa Schüler-Goldbach,

Göttingen University, Germany

*Correspondence:

Jefferson N. Radaeski

jefferson.radaeski@gmail.com

Specialty section:

This article was submitted to Agroecology and Land Use Systems,

a section of the journal

Frontiers in Plant Science

Received: 18 August 2016 Accepted: 21 November 2016 Published: 06 December 2016

Citation:

Radaeski JN, Bauermann SG and Pereira AB (2016) Poaceae Pollen from Southern Brazil: Distinguishing Grasslands (Campos) from Forests by Analyzing a Diverse Range of Poaceae

Species. Front. Plant Sci. 7:1833. doi: $10.3389 / f p l s .2016 .01833$ and grassland species. Discriminant analysis identified three distinct groups representing each vegetation type. Through the pollen measurements we established three pollen types: larger grains $(>46 \mu \mathrm{m})$, from the Bambuseae pollen type, medium-sized grains (46-22 $\mu \mathrm{m})$, from herbaceous pollen type, and small grains $(<22 \mu \mathrm{m})$, from grassland pollen type. The results of our compiled Poaceae pollen dataset may be applied to the fossil pollen of Quaternary sediments.

Keywords: pollen morphology, grasses, pampa, South America, Atlantic forest, bamboo pollen

\section{INTRODUCTION}

Pollen grains of the family Poaceae are widely found in Quaternary sediments of southern Brazil (e.g., Behling et al., 2004; Macedo et al., 2007; Bauermann et al., 2008). However, the stenopalynous nature of the pollen from this family makes it difficult to determine subfamilies and genera using pollen data (Erdtman, 1952; Salgado-Labouriau, 1973). Consequently, low taxonomic resolution hampers paleoecological inferences. Being mainly associated with grassland vegetation (Figure 1), Poaceae pollen is usually interpreted as indicative of open formations. However in Rio Grande do Sul (RS), where more than $80 \%$ of Poaceae species occupy grasslands, a significant percentage (20\%) of representatives of this family inhabit forest vegetation (Boldrini and Longhi-Wagner, 2011).

Although the Poaceae family is well represented and studied in RS, few studies have examined the pollen representatives of this family. The few descriptions or illustrations of pollen representatives presented in the study by Tedesco et al. (1999), which analyzed the diameter of the pollen grains of Hemarthria altissima under different ploidy levels, noted that the average diameters were variable, depending on the ploidy. However, the analyzed pollen grains were not acetolyzed. Medeanic et al. (2008) illustrated images of pollen grains from nine species, while Wilberger et al. (2004) presented images of pollen grains corresponding to three separate species. Nakamura et al. (2010), addressing the development of anther and pollen grains in Axonopus aureus, Chloris elata, h 

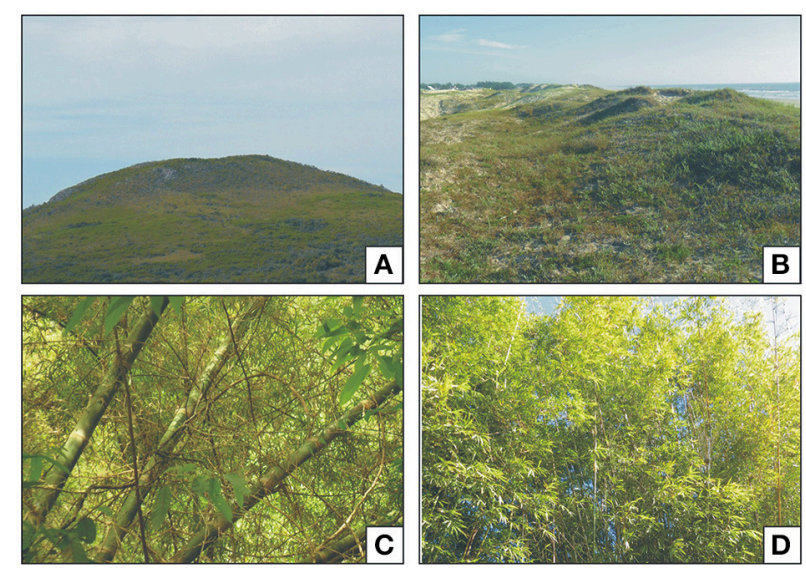

FIGURE 1 | (A) Grassland vegetation of Rio Grande do Sul, "Cerro do Ouro," São Gabriel city. (B) Grassland of the coastal plain of RS, "Balneário Quintão," Palmares do Sul city. (C,D) Riparian forest with lignified bamboos, Gravataí city.

Eragrostis solida, Olyra humilis, Paspalum polyphyllum, and Sucrea monophylla, found similar pollen morphology between taxa. This excludes those grains that have been observed to have patterns that are important for differentiation between species of the family. Radaeski et al. (2011) described the pollen morphology of Paspalum notatum, Paspalum plicatulum, and Schizachyrium microstachyum. Later, Bauermann et al. (2013) described the pollen grains of Andropogon lateralis and Eragrostis bahiensis. Radaeski et al. (2014a) described the pollen morphology of Eragrostis neesii, and Radaeski et al. (2014b) contributed to the pollen description of six taxa of Poaceae, which showed that, in general, the pollen grains are of average size, with a monoaperture and spherical forms, and noted the identified stenopalynous characteristic of the family.

In South America, studies have been conducted on Poaceae pollen grains from Venezuela, Chile, Brazil, and Argentina (Heusser, 1971; Markgraf and D’Antoni, 1978; SalgadoLabouriau and Rinaldi, 1990). In Chile, the overlap between dimensions of the pollen grains of some tribes made it difficult to differentiate between tribes or subfamilies (Heusser, 1971). Thus, further studies on the pollen grains from other taxa are needed. Likewise, the same is true of the pollen grains of Barro Colorado Island (Roubik and Moreno, 1991). However, analyses of many species that are based solely on one pollen grain cannot verify the variations in total pollen grain diameter of the species. Analyzing pollen grains from Argentina, Markgraf and D'Antoni (1978) observed-from other grassland species studied-the largest diameter of pollen grain of the bamboo Chusquea culeou. Thus, analysis of pollen grains from other forest species can provide patterns related to vegetation from this site.

The pollen grains of many species from other regions of the world (e.g., Europe, South America) have been analyzed by scanning electron microscopy (SEM). Some of these species also inhabit southern Brazil. Some studies (Table 1) have explored the surface of the Poaceae pollen grains through SEM, which has contributed to separation of taxonomic groups (Köhler and Lange, 1979; Linder and Ferguson, 1985; Chaturvedi et al., 1994,
TABLE 1 | Dataset of Poaceae analyzed species, type of microscopy used and vegetation type.

\begin{tabular}{|c|c|c|c|}
\hline $\begin{array}{l}\text { Vegetation } \\
\text { type }\end{array}$ & $\begin{array}{l}\text { Microscopy } \\
\text { type }\end{array}$ & $\begin{array}{l}\text { Number of } \\
\text { species }\end{array}$ & Reference \\
\hline Grassland & SEM & 5 & Ahmad et al., 2011 \\
\hline Grassland & LM & 2 & Bauermann et al., 2013 \\
\hline Grassland & LM/SEM & 4 & Chaturvedi and Datta, 2001 \\
\hline Grassland & SEM & 2 & Chaturvedi et al., 1994 \\
\hline Grassland & LM/SEM & 19 & Chaturvedi et al., 1998 \\
\hline $\begin{array}{l}\text { Grassland/ } \\
\text { Forest }\end{array}$ & LM/SEM & 30 & Côrrea et al., 2005 \\
\hline Grassland & LM/SEM & 6 & Datta and Chaturvedi, 2004 \\
\hline $\begin{array}{l}\text { Grassland/ } \\
\text { Forest }\end{array}$ & SEM & 86 & Dórea, 2011 \\
\hline $\begin{array}{l}\text { Grassland/ } \\
\text { Forest }\end{array}$ & LM & 16 & Heusser, 1971 \\
\hline Grassland & LM & 160 & Jan et al., 2014 \\
\hline Grassland & LM & 35 & Joly et al., 2007 \\
\hline Grassland & LM/SEM & 2 & Kashikar and Kalkar, 2010 \\
\hline Grassland & LM & 11 & Katsiotis and Forsberg, 1995 \\
\hline Grassland & SEM & 12 & Köhler and Lange, 1979 \\
\hline Grassland & LM/SEM & 1 & Linder and Ferguson, 1985 \\
\hline Grassland & SEM & 57 & Liu et al., 2004 \\
\hline Grassland & LM/SEM & 1 & Liu et al., 2005 \\
\hline $\begin{array}{l}\text { Grassland/ } \\
\text { Forest }\end{array}$ & SEM & 19 & Mander and Punyasena, 2016 \\
\hline Grassland & SEM & 12 & Mander et al., 2013 \\
\hline Grassland & SEM & 12 & Mander et al., 2014 \\
\hline $\begin{array}{l}\text { Grassland/ } \\
\text { Forest }\end{array}$ & LM & 17 & Markgraf and D'Antoni, 1978 \\
\hline Grassland & LM & 9 & Medeanic et al., 2008 \\
\hline Grassland & LM & 3 & Melhem et al., 2003 \\
\hline Grassland & LM/SEM & 45 & Morgado et al., 2015 \\
\hline $\begin{array}{l}\text { Grassland/ } \\
\text { Forest }\end{array}$ & LM & 6 & Nakamura et al., 2010 \\
\hline Grassland & LM/SEM & 4 & Nazir et al., 2013 \\
\hline Grassland & LM/SEM & 31 & Needham et al., 2015 \\
\hline Grassland & LM/SEM & 54 & Perveen and Qaiser, 2012 \\
\hline Grassland & LM/SEM & 20 & Perveen, 2006 \\
\hline Grassland & LM & 3 & Radaeski et al., 2011 \\
\hline Grassland & LM & 1 & Radaeski et al., 2014a \\
\hline Grassland & LM & 6 & Radaeski et al., 2014b \\
\hline $\begin{array}{l}\text { Grassland/ } \\
\text { Forest }\end{array}$ & LM & 64 & Roubik and Moreno, 1991 \\
\hline $\begin{array}{l}\text { Grassland/ } \\
\text { Forest }\end{array}$ & LM & 49 & $\begin{array}{l}\text { Salgado-Labouriau and Rinaldi, } \\
1990\end{array}$ \\
\hline Grassland & LM & -(fossil pollen) & Schüler and Behling, 2011a \\
\hline Grassland & LM & -(fossil pollen) & Schüler and Behling, 2011b \\
\hline $\begin{array}{l}\text { Grassland/ } \\
\text { Forest }\end{array}$ & SEM & 11 & Skvarla et al., 2003 \\
\hline Grassland & LM & 1 & Tedesco et al., 1999 \\
\hline Grassland & LM & 3 & Wilberger et al., 2004 \\
\hline
\end{tabular}

1998; Chaturvedi and Datta, 2001; Skvarla et al., 2003; Datta and Chaturvedi, 2004; Liu et al., 2004, 2005; Perveen, 2006; Kashikar and Kalkar, 2010; Ahmad et al., 2011; Dórea, 2011; 
Perveen and Qaiser, 2012; Mander et al., 2013, 2014; Nazir et al., 2013; Morgado et al., 2015; Needham et al., 2015; Mander and Punyasena, 2016). However, other studies using light microscopy (LM) have shown morphometric differences in the size of the Poaceae pollen grain species (Salgado-Labouriau and Rinaldi, 1990; Katsiotis and Forsberg, 1995; Joly et al., 2007; Schüler and Behling, 2011a,b; Jan et al., 2014). In addition, when analyzing large sets of palynomorphs from quaternary sediments, the use of SEM is a difficult and time-consuming task. Thus, morphometric datasets may be valuable for use in studies of fossil Poaceae pollen analysis (Schüler and Behling, 2011a,b; Jan et al., 2014).

Recently, studying pollen grains of fossil Poaceae in the grassland ecosystems of South America, Schüler and Behling (2011a) discovered potential new ways to distinguish grassland types. In their later study, Schüler and Behling (2011b) were able to differentiate the ecosystems present in South America. Moreover, Jan et al. (2014) succeeded in identifying a pattern among changes in the size of Poaceae pollen grains according to the ploidy level and $\mathrm{C}_{3}$ and $\mathrm{C}_{4}$ metabolism, thereby demonstrating that polyploid species have a larger pollen grain size. $\mathrm{C}_{4}$ species are tropical and inhabit warmer and drier regions, while temperate Poaceae species are $\mathrm{C}_{3}$ and live in humid and cold conditions (Boldrini, 2006). $\mathrm{C}_{3}$ and $\mathrm{C}_{4}$ species are important for paleoclimate studies because they indicate past variation in temperature and precipitation (Schüler and Behling, 2011a).

The aim of the study was to distinguish Poaceae pollen grains from grassland and forest vegetation of southern Brazil. The pollen grains of 68 species were analyzed to answer the following questions: (1) Can Poaceae pollen grains be separated into those of grassland species and those of forest species? (2) Do the pollen grains of forest species differ in size according to their arboreal or herbaceous habit?

\section{MATERIALS AND METHODS \\ Collection of Botanical Material}

During the field expeditions, 98 specimens of Poaceae were obtained, anticipating the 21 taxa representatives of this family, and some pollen material, being fertile, was selected for extraction. To obtain hibernal and estival plants in the flowering seasons, the samples were gathered using the transversal method (Filgueiras et al., 1994) in winter, autumn, spring, and summer in May, August, September, October, November, and December of 2013, as well as in January of 2014.

After collection, the plants were pressed and dehydrated. The plants were identified by a skilled taxonomist (A. A. Schneider). The collection of herbarium specimens was deposited in the "Herbário do Museu de Ciências Naturais" from the Universidade Luterana do Brasil (MCNU/HERULBRA), and duplicates were deposited in the "Herbário Bruno Edgar Irgang” from Unipampa (HBEI/UNIPAMPA). The anthers were collected for chemical treatment of the herbarium materials from other Poaceae species. Since some species have state-restricted distribution, or sporadic bloom periods, samples were collected from pollen material in accordance with information provided by the ICN Herbarium (Figure 2, Table 2).

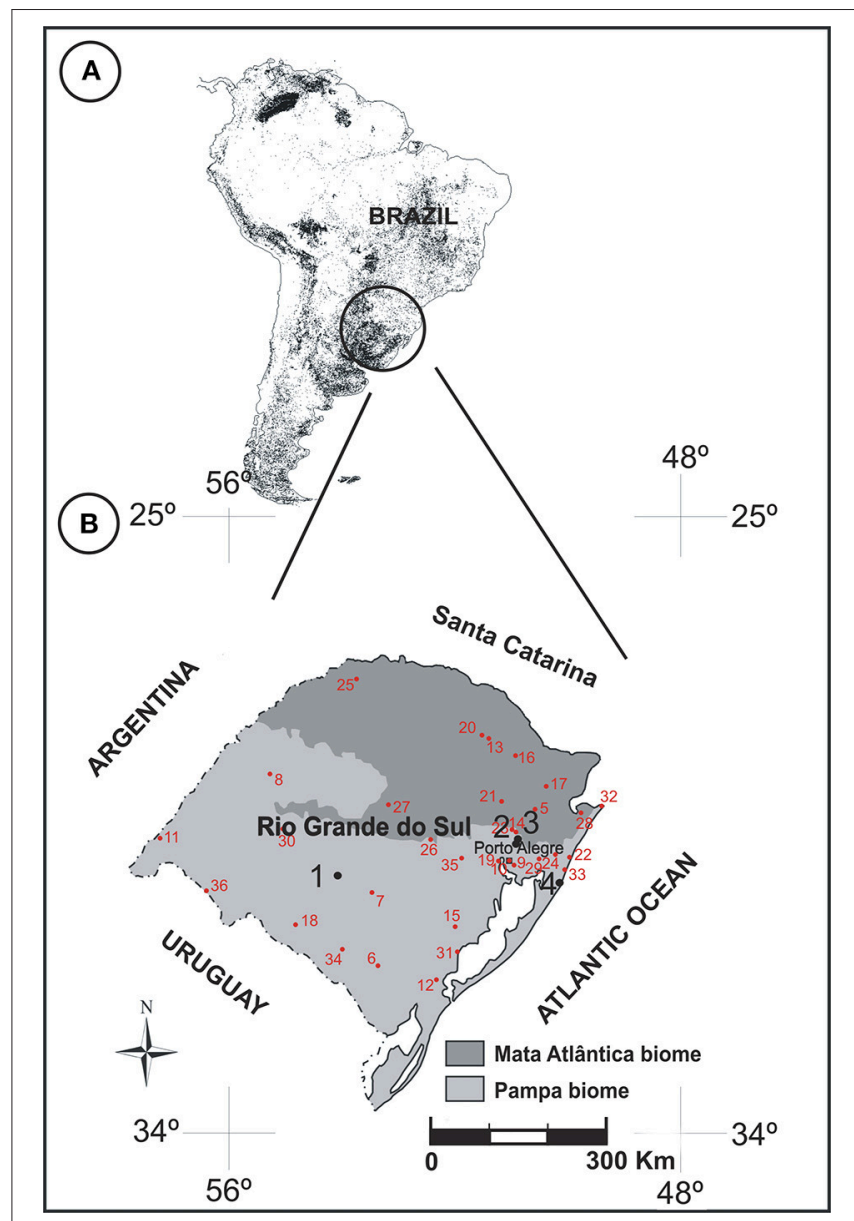

FIGURE 2 | (A) Distribution of grasslands in South America highlighting the southern region of Brazil (adapted from Eva et al., 2002). (B) Map of Rio Grande do Sul showing the sampling sites in RS (black circles): 1. "Cerro do Ouro," São Gabriel city; 2. Cachoeirinha city; 3. "Sitio Laranjal," Gravataí city; 4. "Balneário Quintão," Palmares do Sul city. Red circles indicate regions of collection of herbarium species (see Table $\mathbf{2}$ for more details of the names of regions).

The collection of pollen materials from a herbarium (containing plants from different regions of the state) enabled the authors of this study to establish an overview of the modern grass pollen of RS. By combining the findings of this study with the work of Hasenack et al. (2010) on the vegetation physiognomy of the state, we were able to establish a relationship between the pollen and the regional flora. Only 50 Poaceae species of four subfamilies comprise forest vegetation. Thus, we considered the selection of 10 forest species from all tribes and subfamilies for pollen analysis to be adequate. More species of grassland (58 species) were analyzed because there are a greater number of Poaceae species (450 species) in southern Brazil (Boldrini and Longhi-Wagner, 2011) than forest species.

\section{Treatment and Description of Pollen Grains}

The anthers were chemically processed according to the acetolysis methodology proposed by Erdtman (1952). After acetolysis, using glycerinated jelly, five permanent slides were 
TABLE 2 | Information of the examined material in the Rio Grande do Sul, Brazil.

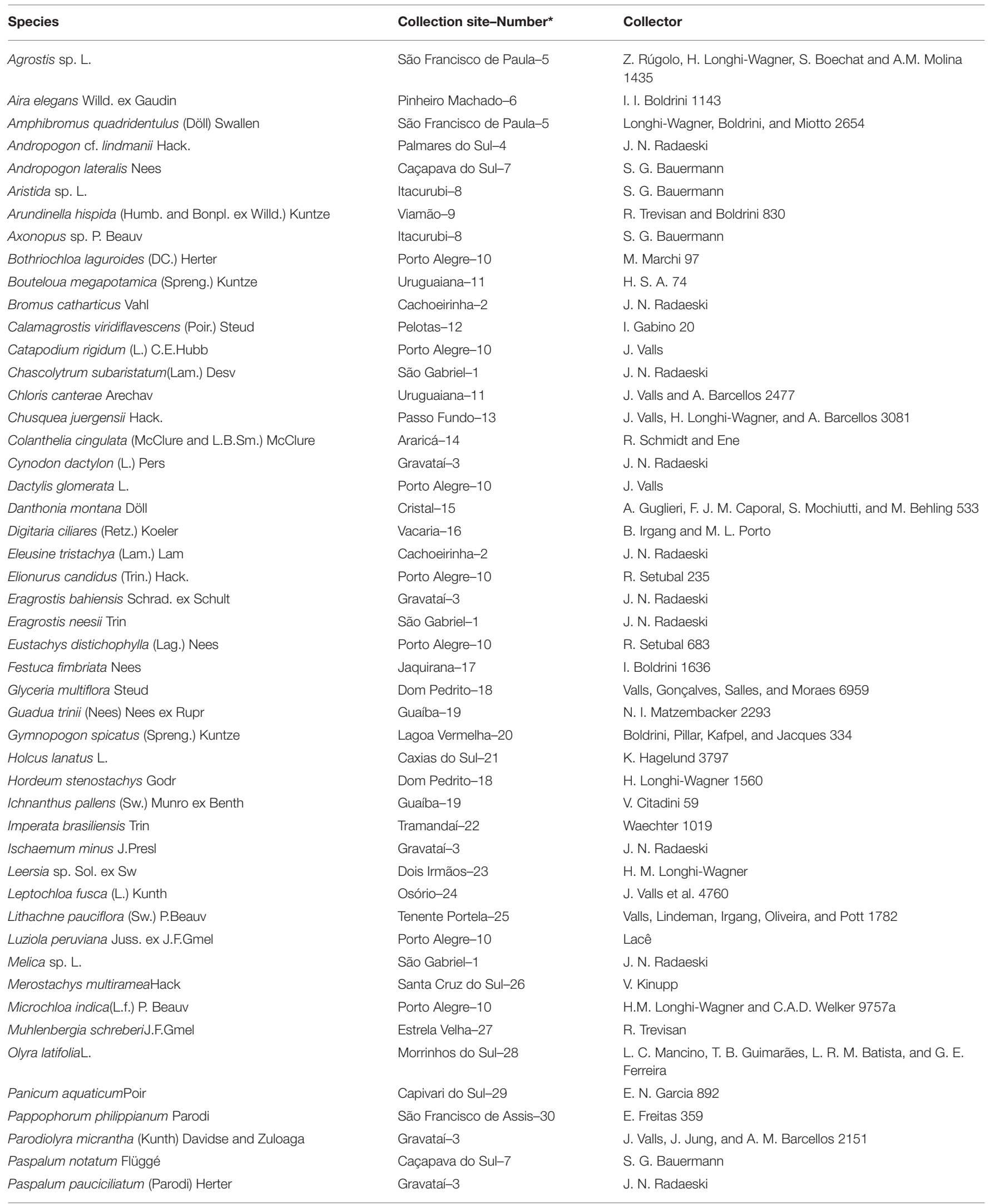


TABLE 2 | Continued

\begin{tabular}{lll}
\hline Species & Collection site-Number* & Collector \\
\hline Paspalum urvillei Steud & Palmares do Sul-4 & J. N. Radaeski \\
Phalaris angusta Nees ex Trin & São Lourenço do Sul-31 & C. Bonilha 486 \\
Pharus lappulaceus Aubl & Gravataí-3 & L. R. M. Baptista \\
Piptochaetium montevidense (Spreng.) Parodi & São Gabriel-1 & J. N. Radaeski \\
Poa bonariensis (Lam.) Kunth & Vacaria-16 & A. Kappel \\
Polypogon elongatus Kunth & Torres-32 & A. Barcelos and B. Irgang 9 \\
Schizachyrium microstachyum (Desv. ex Ham.) Roseng & Caçapava do Sul-7 & S. G. Bauermann \\
Setaria parviflora (Poir.) Kerguélen & Gravataí-3 & J. N. Radaeski \\
Spartina ciliata Brongn & Cidreira-33 & H. M. Longhi-Wagner and S. Leite \\
Sporobolus indicus (L.) R.Br & Gravataí-3 & J. N. Radaeski \\
Stipa filifolia Nees & Bagé-34 & H. M. Longhi-Wagner 5042 \\
Stipa melanosperma J. Presl & São Francisco de Paula-5 & R. L. C. Bortoluzzi 816 \\
Stipa papposa Nees & Bagé-34 & I. Boldrini 1177 \\
Stipa setigera J.Presl & Bagé-34 & S. C. Boechat \\
Streptochaeta spicata Schrad. ex Nees & Torres-32 & J. F. M. Valls 1055 \\
Tridens brasiliensis (Nees ex Steud.) Parodi & Cachoeira do Sul-35 & J. Valls \\
Trachypogon filifolius (Hack.) Hitchc & Quaraí-36 & Boldrini and Pilz187 \\
Tripogon spicatus (Nees) Ekman & Quaraí-36 & Boldrini, Barreto, Boechat and Pillar 279 \\
\hline
\end{tabular}

${ }^{\star}$ Numbers corresponding to the Map of Figure $\mathbf{2 B}$.

created for each sample and deposited in the Laboratório de Palinologia da ULBRA. The pollen grains were measured and the slides mounted on the same day to prevent any changes in pollen size (Salgado-Labouriau, 2007). Schüler and Behling (2011a) measured 60 pollen grains from fossil pollen samples, but in this paper we studied modern pollen grains, measuring 25 pollen grains according to the methodology used for the study of modern pollen grains (Erdtman, 1952; Barth and Melhem, 1988).

The morphological characteristics of the pollen grains were observed and described by LM. A Leica CME microscope was used for measurements and for recording images. Using $\mathrm{a} \times 1000$ magnification, we recorded the polar diameter $(\mathrm{P})$, equatorial diameter (E), or only the diameter (D) of spherical pollen grains, and the thickness of the exine (Ex) in 25 randomly selected pollen grains. In addition to the above, measurements of the pore and annulus width of the studied species were recorded (Figure 3). The pollen grains were then described in regard to their pollen unit, size, symmetry, polarity, amb, type of aperture, and ornamentation, using the terminology proposed by Barth and Melhem (1988) and Punt et al. (2007).

\section{Statistical Analysis}

BioEstat 5.0 and PAST 3.05 software was used for the statistical analysis. BioEstat 5.0 software was used to compile a frequency distribution histogram of pollen grain sizes. The histogram was then constructed from the size of the pollen grains of species inhabiting arboreous forest, grassland, and herbaceous forest. This program (BioEstat 5.0) was also used to determine size differences among pollen grains from arboreous forest, grassland, and herbaceous forest species using One-way ANOVA followed by Tukey's test. PAST 3.05software was used for discriminant analysis (DA) of separate groups according to the size of the

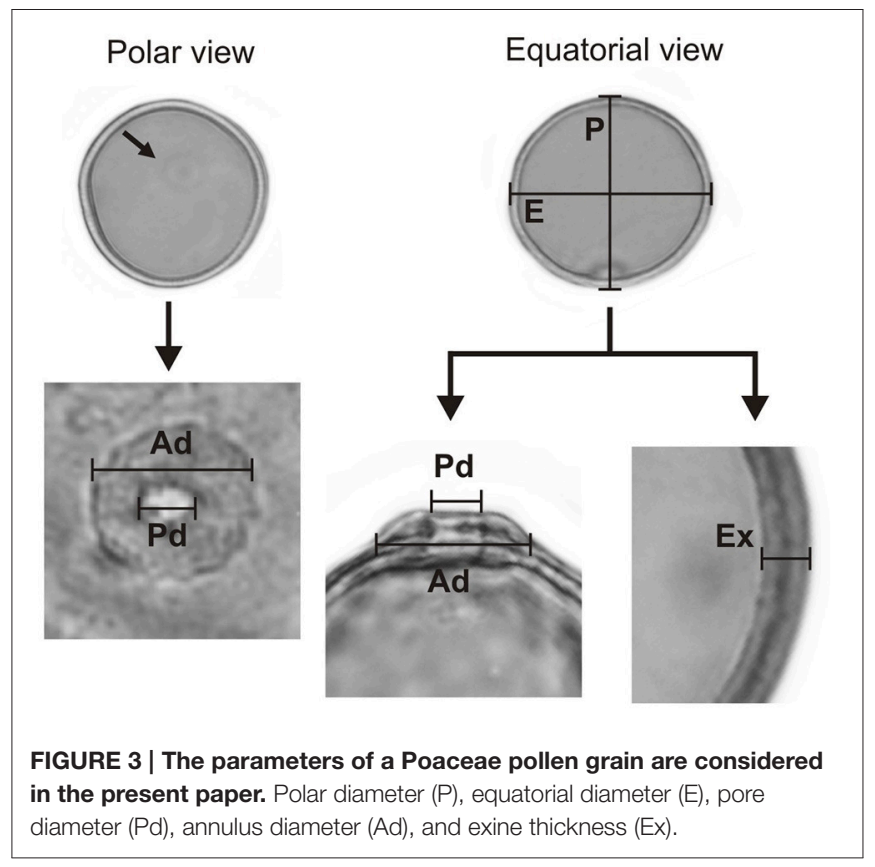

pollen grains. In DA we use the minimum, maximum, and average size of pollen grains of all species to determine whether they can be grouped. We used this program (PAST 3.05) also to show the correlation between pollen grain, annulus, and pore sizes by Pearson correlation. The Pearson's correlation coefficient test was used to determine the average size of the pollen grains, the pore width, and the annulus width for all species (68 species studied). The PAST 3.05 software was also used to construct a box plot. The box plot shows overlapping measures and measures that 


\begin{tabular}{|c|c|c|c|c|}
\hline 离 & 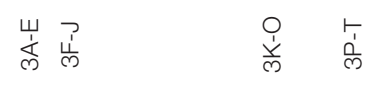 & 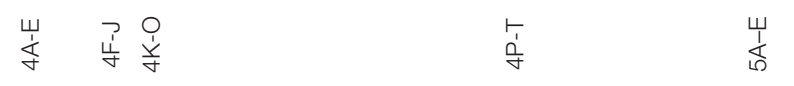 & 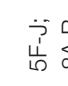 & \\
\hline 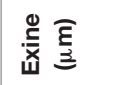 & 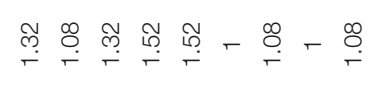 & 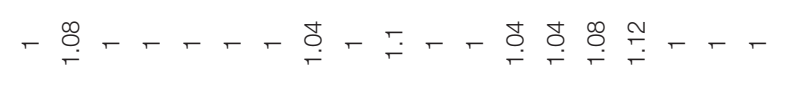 & $\stackrel{\infty}{\stackrel{\infty}{+}}$ & $-\stackrel{+}{\stackrel{+}{0}}-$ \\
\hline 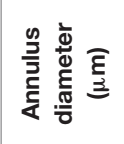 & 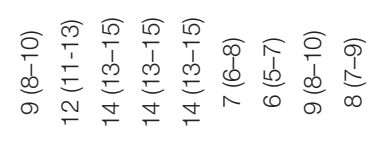 & 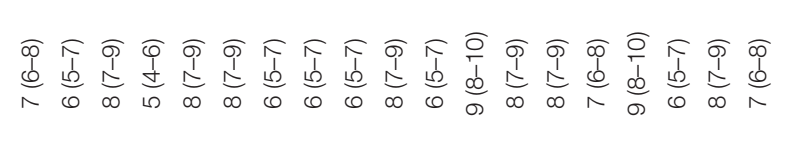 & $\underset{\infty}{\frac{9}{1}}$ & 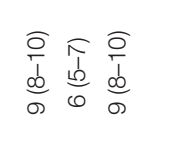 \\
\hline 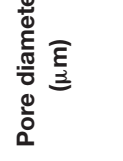 & 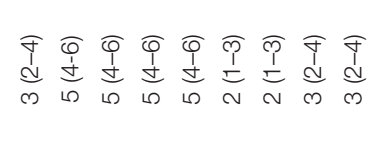 & 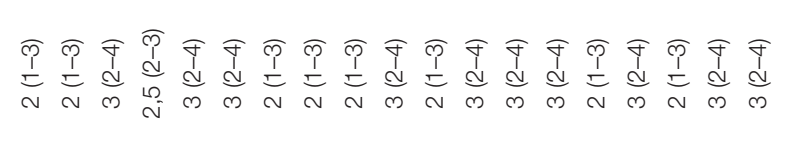 & $\frac{q}{d}$ & 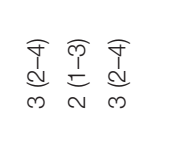 \\
\hline 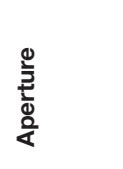 & 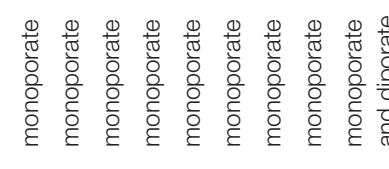 & 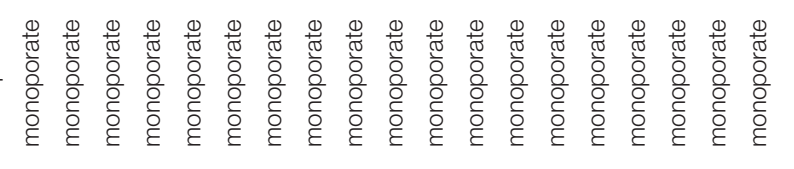 & 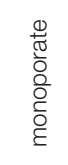 & 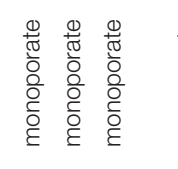 \\
\hline
\end{tabular}




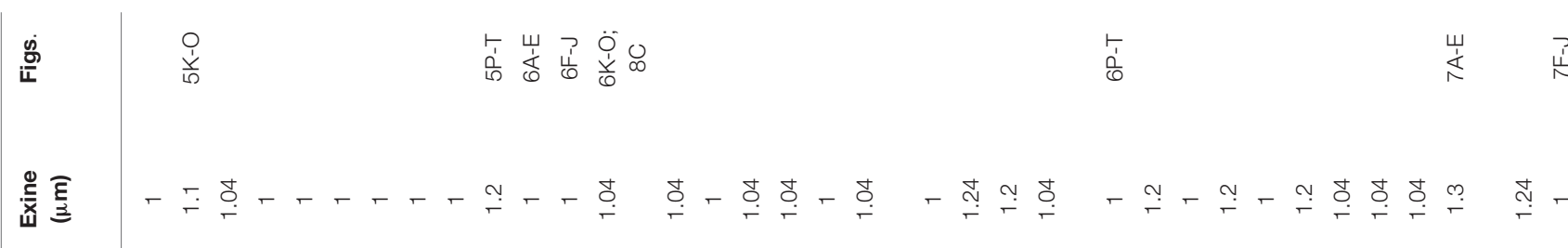

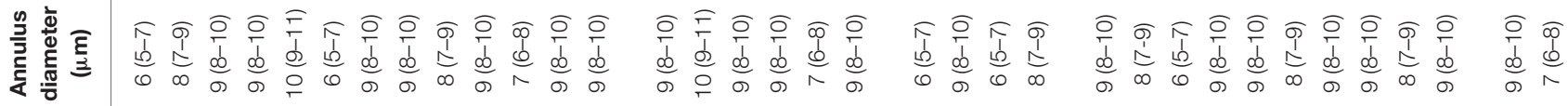

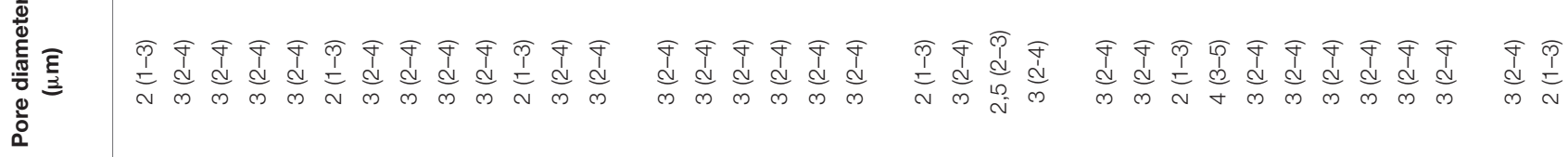
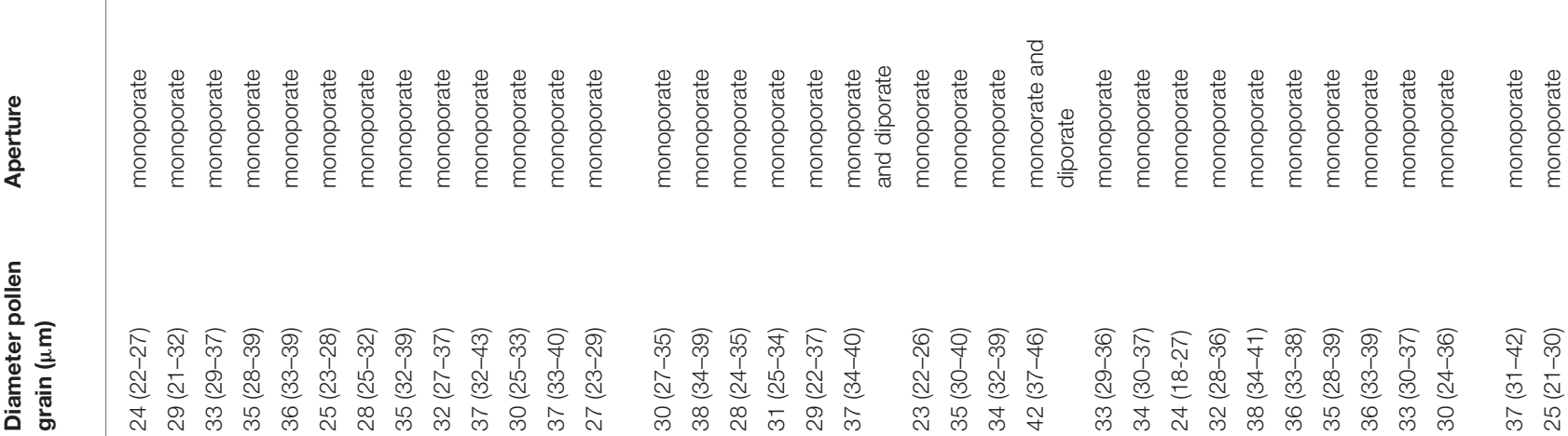

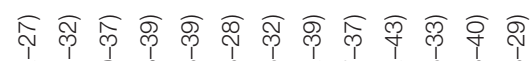

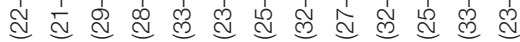

贾贾贾居命导

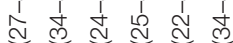

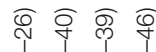

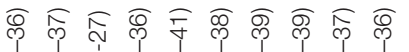

勇 $\overline{\mathrm{p}}$

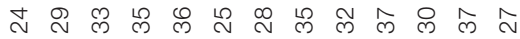

ठํㅆ

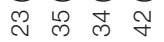

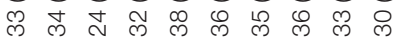

ले «্

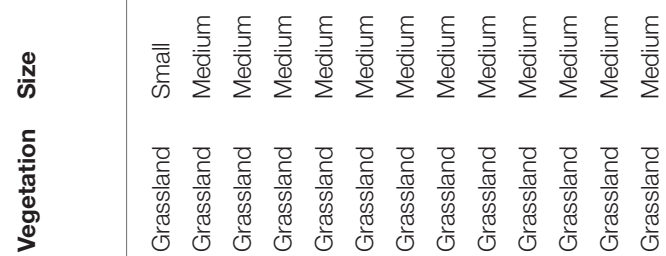

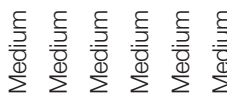

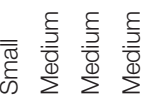

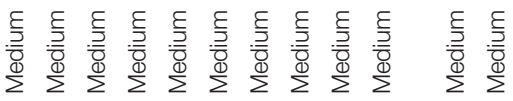

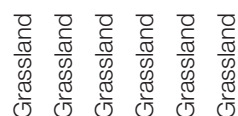

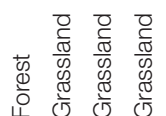
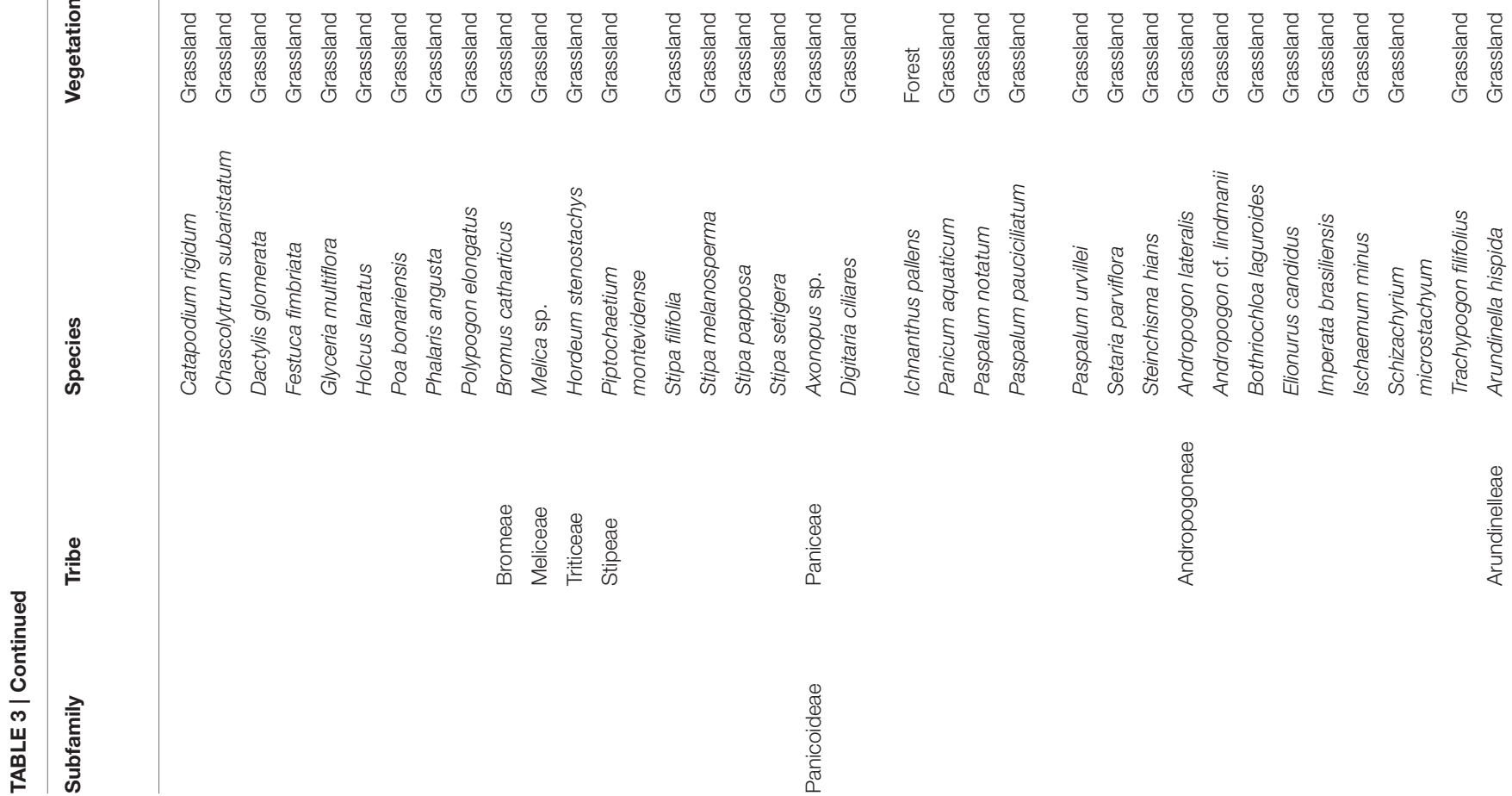

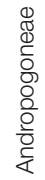



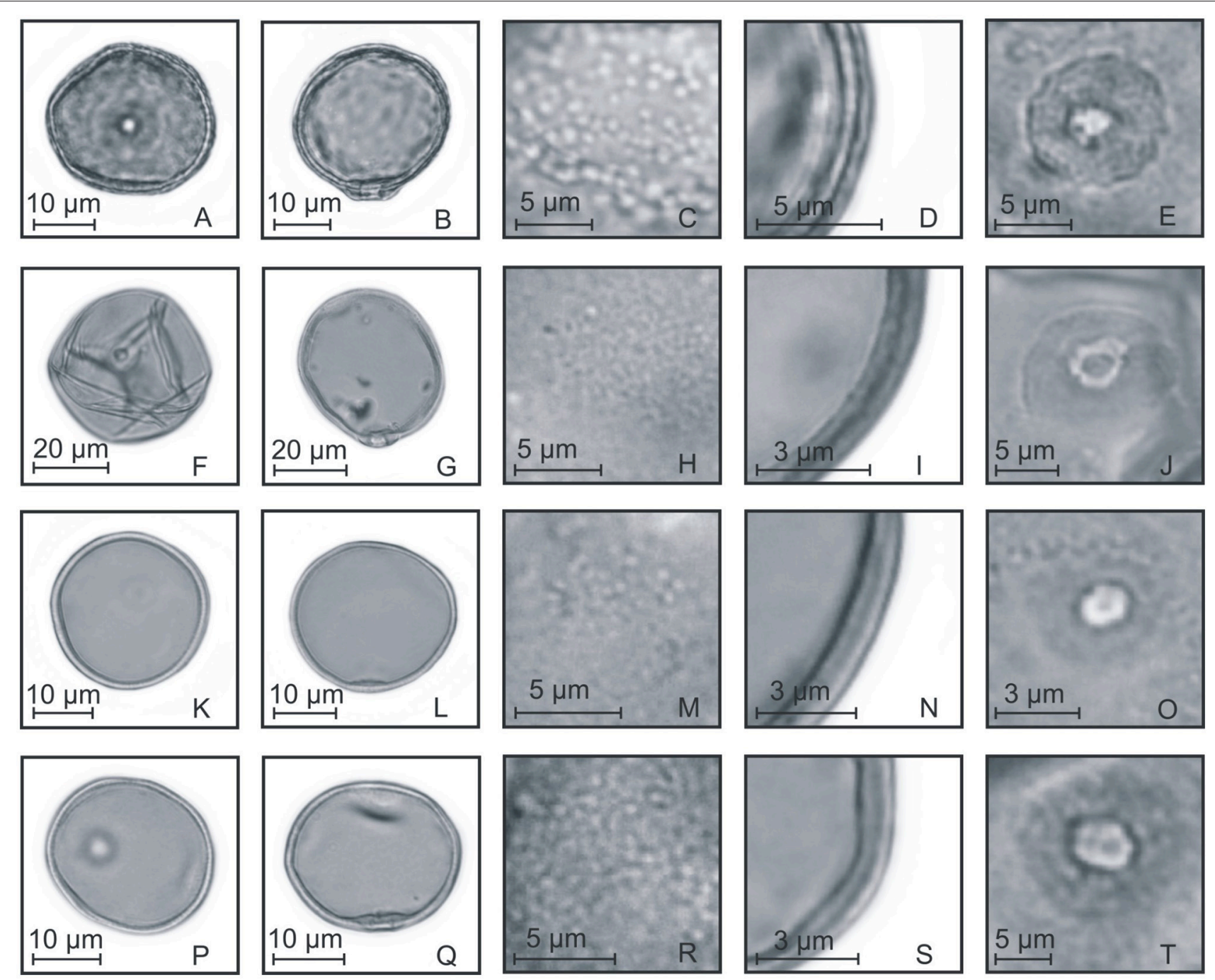

FIGURE 4 | Pollen grains of the subfamilies Anomochlooideae, Bambusoideae, and Pharoideae. (A-E) Streptochaeta spicata: PV (A), EV (B), detail of ornamentation (C), detail of the thickness of the exine (D), and detail of the aperture (E); (F-J) Chusquea juergensii: PV (F), EV (G), detail of ornamentation (H), detail of the thickness of the exine (I), and detail of the aperture (J); (K-O) Olyra latifolia: PV (K), EV (L), detail of ornamentation (M), detail of the thickness of the exine (N), and detail of the aperture $(\mathbf{O})$; (P-T) Pharus lappulaceus: PV (P), EV (Q), detail of ornamentation $(\mathbf{R})$, detail of the thickness of the exine (S), and detail of the aperture (T).

do not overlap. We used all the pollen grain size measurements for the box plot (i.e., 25 measures each of 68 species $=$ total 1700 measures).

\section{RESULTS}

\section{Measurement of Pollen Grains}

Table 3 presents the measurements of the pollen grains for the 68 species, in evolutionary order according to the GPWG (Grass Phylogeny Working Group) classification (2001). Yet, differences were observed in the measurements of pollen grains, pores, and annulus. Pollen grains of species of each tribe were selected to show the Poaceae morphological characteristics of all the tribes of southern Brazil (Figures 4-8).

A frequency distribution histogram of the measurements of pollen size is shown in Figure 9A. The average measurement values were higher for arboreous forest ( $8 \%$ of the measurements of these species were $50 \mu \mathrm{m}$ ). Grassland and herbaceous forest species had lower average measurement values (16\% of the forest herbaceous species measured $27 \mu \mathrm{m}$, and $8 \%$ of the grassland species measured $32 \mu \mathrm{m}$ ). Grain size distributions showed a Gaussian distribution for samples of arboreous forest, grassland, and herbaceous forest species (Figures 9B-E). The Gaussian distribution showed that ANOVA-Tukey can be applied to the data set.

\section{Morphometric Variation in Diameters of the Pollen Grains, Pores, and Annulus}

The ANOVA-Tukey test showed statistically significant differences between the size of pollen grains of arboreous forest, grassland, and herbaceous forest species (Table 4). This difference is clear in the comparison of samples that indicate 

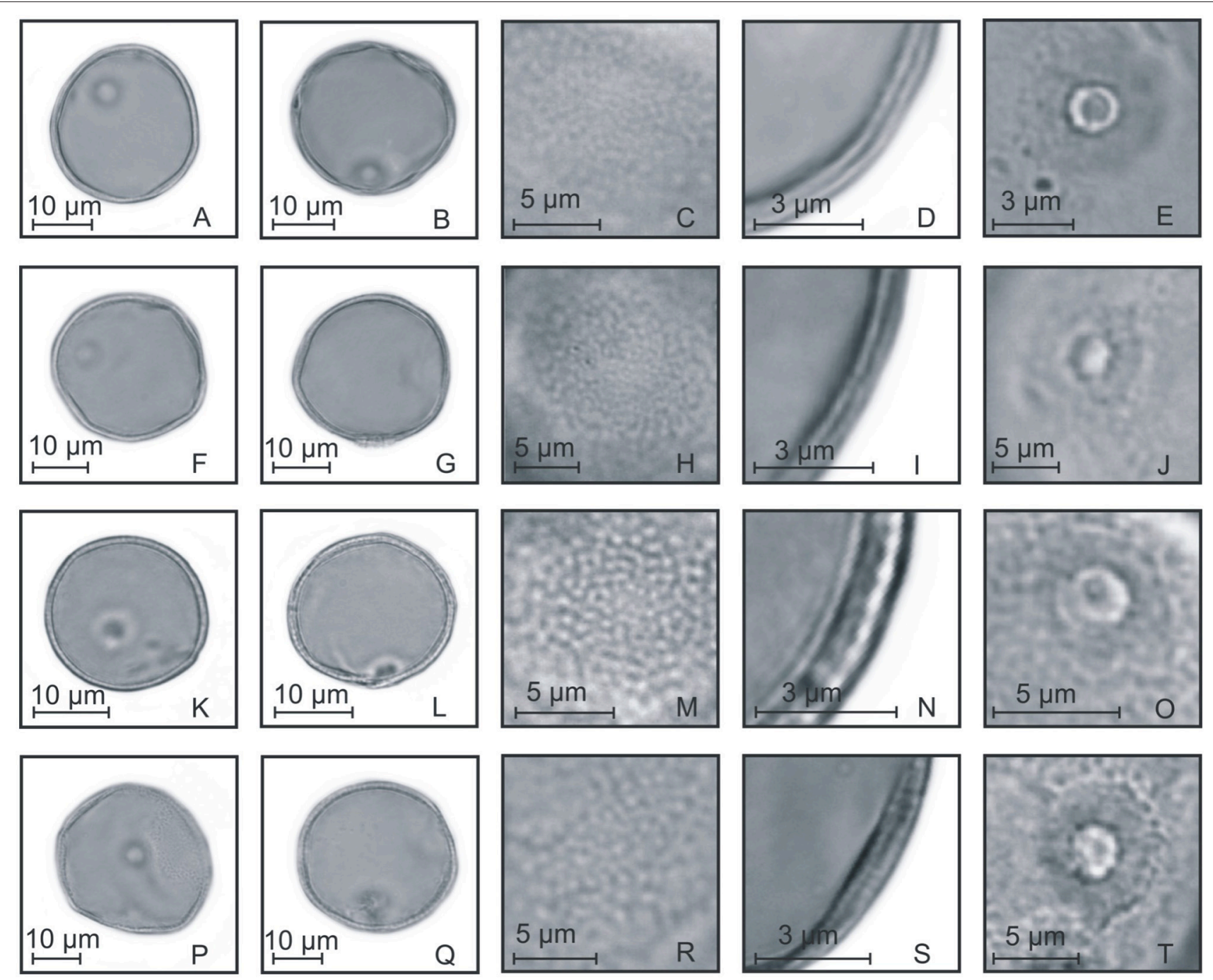

FIGURE 5 | Pollen grains of the subfamilies Ehrarthoideae, Danthonioideae, and Chloridoideae. (A-E) Leersia sp.: PV (A), EV (B), detail of ornamentation (C), detail of the thickness of the exine (D), and detail of the aperture (E); (F-J) Danthonia montana: PV (F), EV (G), detail of ornamentation (H), detail of the thickness of the exine (I), and detail of the aperture (J); (K-O) Eragrostis neesii: PV (K), EV (L), detail of ornamentation (M), detail of the thickness of the exine (N), and detail of

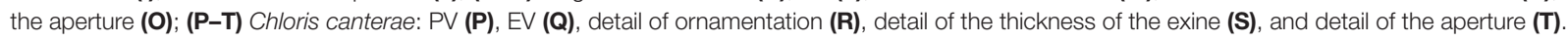

values $(p)$ less than 0.01 . The difference between the means of the arboreous forest and grassland samples was large (22.1719), while among the grassland and herbaceous forest samples the difference was small (4.3681).

The DA test (Figure 10) determined the separation of three groups according to the values of the variables. The DA identified the separation of arboreous forest grassland and herbaceous forest groups. The arboreous forest group showed the greatest differences, and the grassland and herbaceous forest groups were mixed.

The Pearson correlation test (Table 5) showed values that indicate a strong relationship between the size of pollen grains and the width of the pore $(r=0.8281)$. It also showed a strong relationship between the size of pollen grains and the width of the annulus $(r=0.8565)$. The diagrams of the values obtained indicate a similarity between the size of pollen grains, the pore width, and the width of the annulus (Figure 11).
All taxa showed monoporate apertures with annulus around the pores, except for Pharus lappulaceus, Digitaria ciliares, and Paspalum pauciciliatum, which showed diporate as well as the monoporate pollen grains. However, these three species $(P$. lappulaceus, D.ciliares, and P. pauciciliatum) showed only a few diporate pollen grains; most of their pollen grains were found to be monoporate. Nevertheless, they were unique species in terms of having diporate pollen. In the herbaceous forest species with diporate pollen grains, the grains measured $23-27 \mu \mathrm{m}$ in width, while in the grassland species with diporate pollen, the grains measured $34-46 \mu \mathrm{m}$ in width.

\section{Interpretation of, and Distinction between, the Grassland and Forest Pollen Grains}

In southern Brazil, $80 \%$ of Poaceae species are grassland species, while $20 \%$ are forest species. In our data set ( 68 species), $85.29 \%$ were grassland species and $14.71 \%$ were forest species. Thus, 

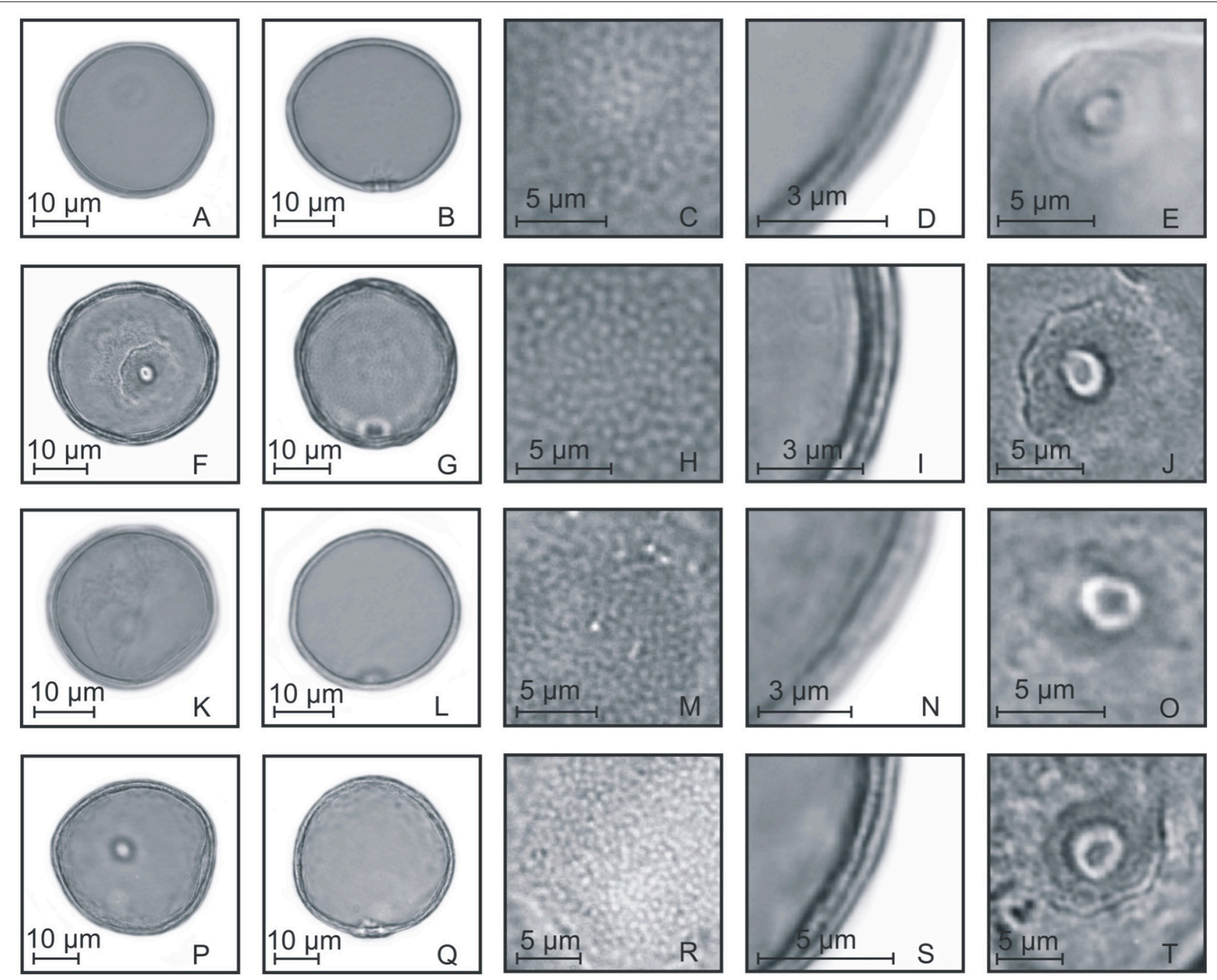

FIGURE 6 | Pollen grains of the subfamilies Chloridoideae, Aristidoideae, and Pooideae. (A-E) Pappophorum philippianum: PV (A), EV (B), detail of ornamentation (C), detail of the thickness of the exine (D), and detail of the aperture (E); (F-J) Aristida sp.: PV (F), EV (G), detail of ornamentation (H), detail of the thickness of the exine (I), and detail of the aperture (J); (K-O) Chascolytrum subaristatum: PV (K), EV (L), detail of ornamentation (M), detail of the thickness of the

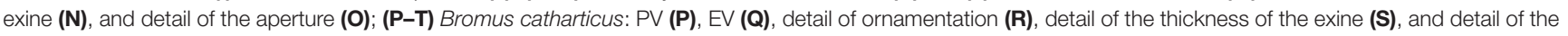
aperture (T).

we analyzed the appropriate proportions of species relating to grassland and forest vegetation in the region.

The box plot of data sets relating to different Poaceae vegetation (arboreous forest, grassland, and herbaceous forest) showed pollen grains of different size ranges (Figure 12). The pollen grains of arboreous forest species were larger than those of grassland and herbaceous forest species. The pollen grains of grassland species and herbaceous forest species were found to be of similar size. However, the pollen of the grassland species had a lower minimum size than that of the forest herbaceous species. Three pollen types could be separated based on pollen grain size (Table 6). The Bambuseae pollen type was found to have pollen grains larger than $46 \mu$ min width. Pollen grains that vary in size between 22 and $46 \mu \mathrm{m}$ are of the herbaceous pollen type; these pollen grains belong to either grassland or herbaceous forest species. The grassland pollen type has small pollen grains, measuring less than $22 \mu \mathrm{m}$.

\section{DISCUSSION}

Based on measurements of pollen grains, previous studies have allowed scholars to distinguish between Poaceae pollen grains of South American ecosystems, and also to show the trends in pollen grain size among $\mathrm{C}_{3}$ and $\mathrm{C}_{4}$ Poaceae species (Schüler and Behling, 2011a,b; Jan et al., 2014). In this work, it was possible to distinguish the Poaceae pollen grains relating to grassland and forest species of southern Brazil. Jan et al. (2014) analyzed a large data set with species from various locations around the 

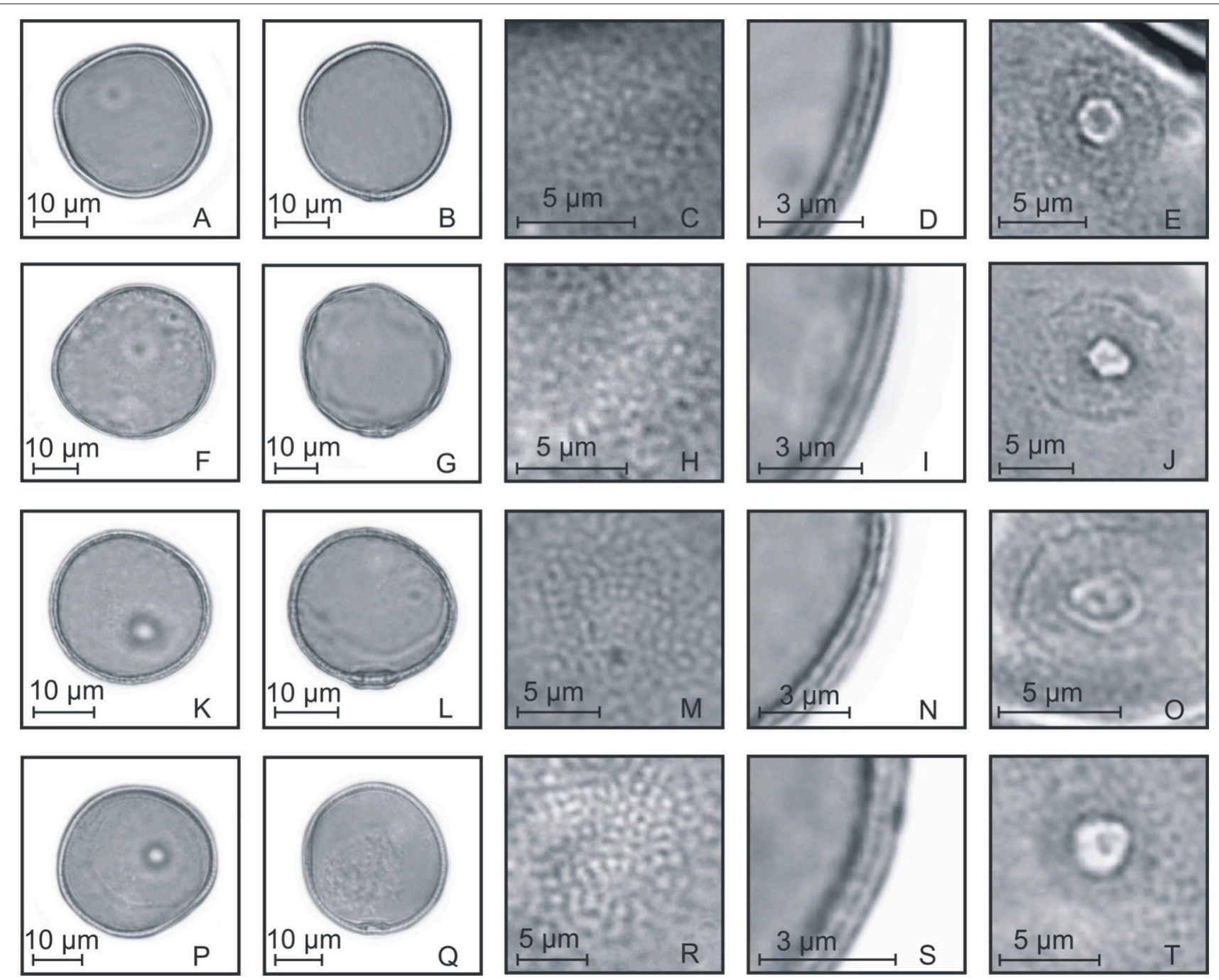

FIGURE 7 | Pollen grains of the subfamilies Pooideae and Panicoideae. (A-E) Melica sp.: PV (A), EV (B), detail of ornamentation (C), detail of the thickness of the exine (D), and detail of the aperture (E); (F-J) Hordeum stenostachys: PV (F), EV (G), detail of ornamentation (H), detail of the thickness of the exine (I), and detail of the aperture (J); (K-O) Piptochaetium montevidense: PV (K), EV (L), detail of ornamentation (M), detail of the thickness of the exine (N), and detail of the aperture (O); (P-T) Paspalum urvillei: PV (P), EV (Q), detail of ornamentation (R), detail of the thickness of the exine (S), and detail of the aperture (T).

world. In our work we wanted to analyze the variability within one ecosystem; therefore, we chose to analyze a large set of data relating to only one region (southern Brazil).

Studies of Poaceae pollen grains have revealed a strong correlation between size of pollen grain, pore, and annulus (Skvarla et al., 2003; Joly et al., 2007; Schüler and Behling, 2011a,b; Jan et al., 2014). The results of our own study also showed a relationship between size of pollen, pore, and annulus, as determined through correlation analysis.

Analysis of the Poaceae pollen of the plants deposited in the herbarium provided a description of the variation in pollen grain size of species that occur in different regions of the state of RS. According to the results, relating pollen data to information on the current vegetation of RS, the main variations in size of Poaceae pollen grains in the state (Figure 13) could be mapped.
Taking into account the vegetation types that are based on more representative genera from different regions (Hasenack et al., 2010), we can assign to regions the probable main pollen types occurring in different locations. Thus, the northern half of RS seems to be composed of larger pollen grains. We also found a reduction in size toward the southern half of the state, where the concentration of smaller pollen grains can be associated with the western part of RS, especially in the region of grassland with shallow soils (where the range of diameters for pollen grains is $22-34 \mu \mathrm{m})$.

\section{Forest Vegetation}

Pollen grains of forest Poaceae species showed distinctions between species. Arboreous species showed larger pollen grains than herbaceous species. The pollen grain size of the arboreous 

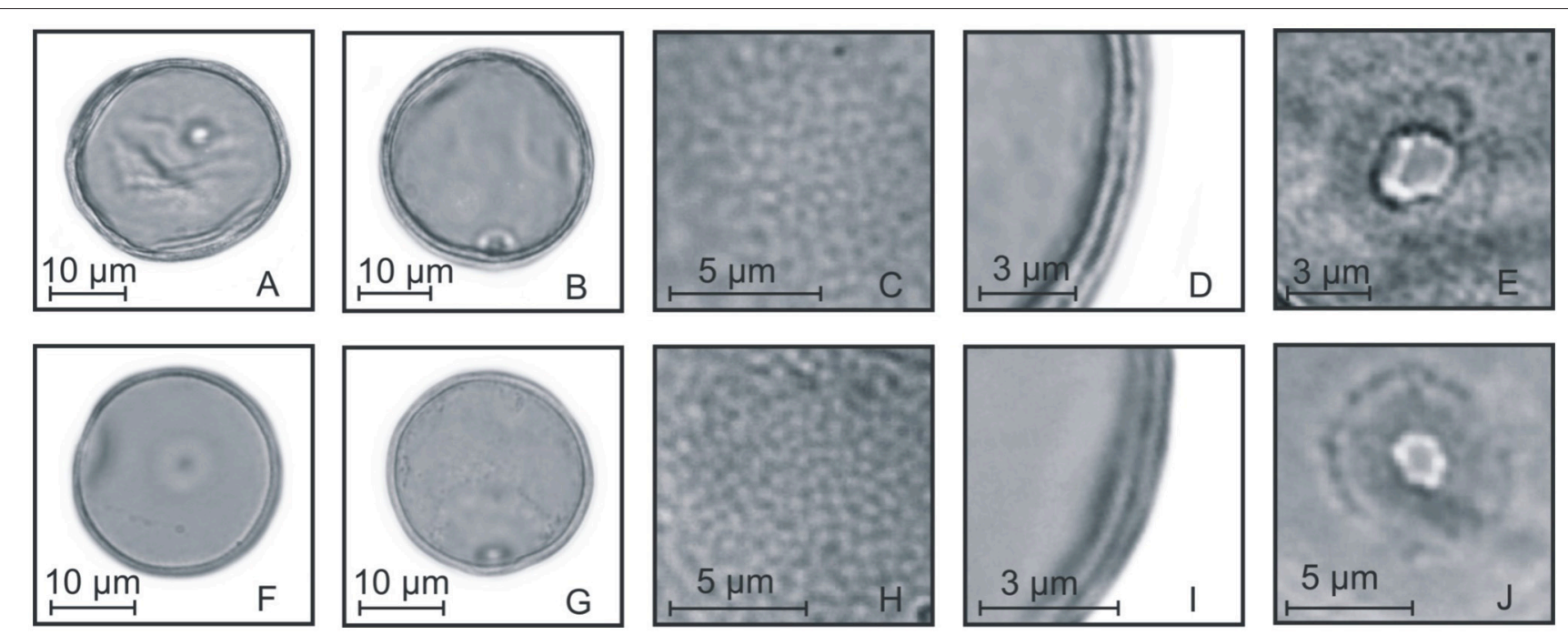

FIGURE 8 | Pollen grains of the subfamily Panicoideae. (A-E) Schizachyrium microstachyum: PV (A), EV (B), detail of ornamentation (C), detail of the thickness of the exine (D), and detail of the aperture (E); (F-J) Arundinella hispida: PV (F), EV (G), detail of ornamentation $(\mathbf{H})$, detail of the thickness of the exine (I), and detail of the aperture $\mathbf{( J )}$.

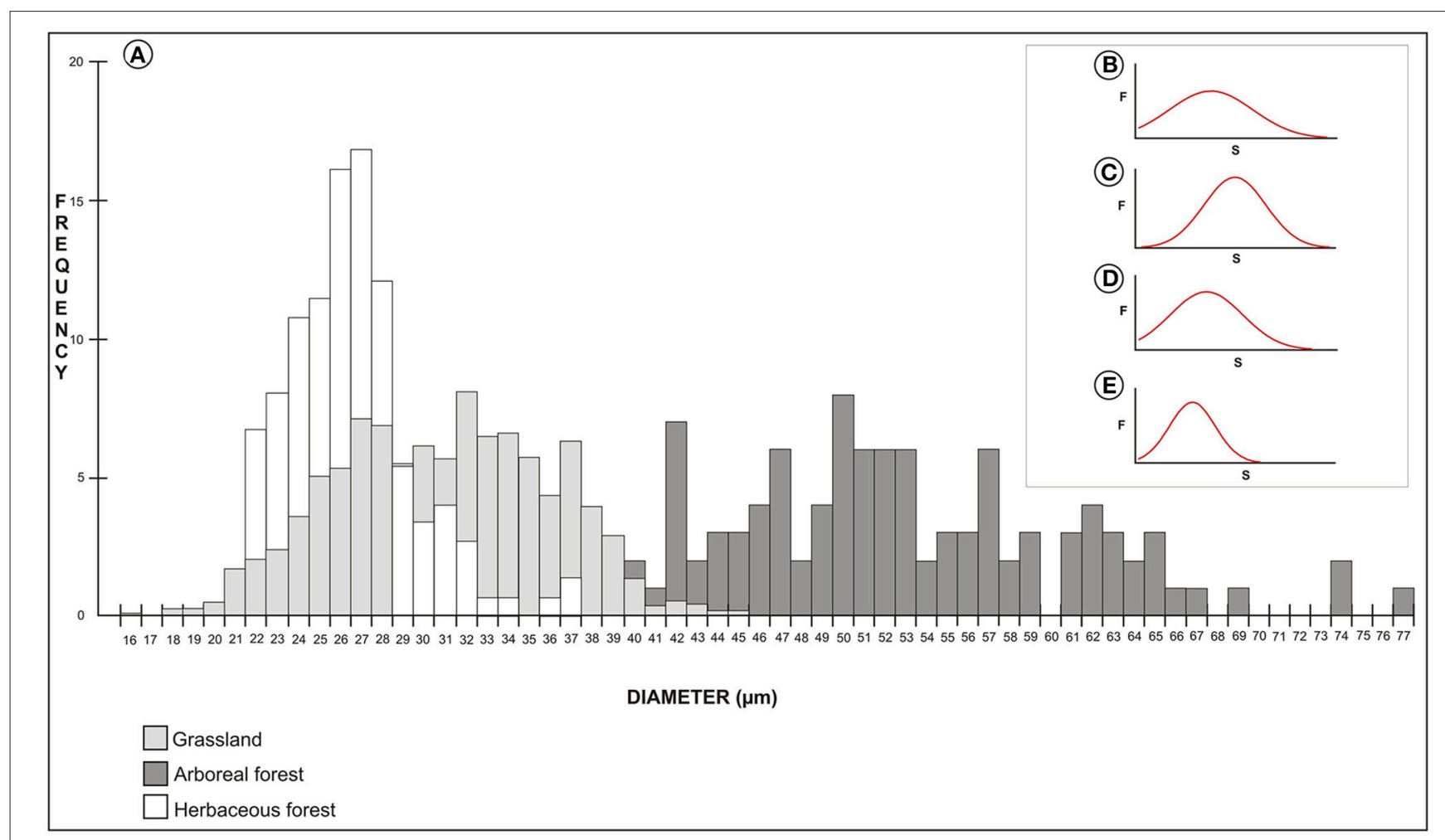

FIGURE 9 | Frequency distribution histogram of the pollen size measurements (A). Gaussian distribution of size measurements of pollen grains of arboreous species (B), grassland species (C), herbaceous forest species (D), and all species studied (E). F, frequency; S, pollen grain size.

species ranged from medium to large, while that of the herbaceous species ranged from small to medium. The pollen grains of arboreous Poaceae species showed a tendency toward larger sizes (Markgraf and D’Antoni, 1978; Salgado-Labouriau and Rinaldi, 1990). The differently sized grains of pollen forest species may be related to the small wind flow inside the forests and may also be influenced by pollination (Dórea, 2011). Some variations in the size of the pollen grains of modern 
TABLE 4 | Significances between the size of pollen grains of forest arboreous, grassland, and forest herbaceous species obtained with ANOVA-Tukey.

\begin{tabular}{|c|c|c|c|}
\hline $\begin{array}{l}\text { Sources of } \\
\text { variation }\end{array}$ & DF & $\begin{array}{l}\text { Sum of } \\
\text { squares }\end{array}$ & $\begin{array}{l}\text { Mean squares } \\
\text { (variances) }\end{array}$ \\
\hline Treatments & 2 & $50.6 e+03$ & $25.3 e+03$ \\
\hline error & 1672 & $45.0 e+03$ & 26.924 \\
\hline $\mathrm{F}=$ & 939.0160 & & \\
\hline$(p)=$ & $<0.0001$ & & \\
\hline $\begin{array}{l}\text { Mean (arboreal forest pollen } \\
\text { grains) }\end{array}$ & 53.0800 & & \\
\hline Mean (grassland pollen grains) & 30.9081 & & \\
\hline $\begin{array}{l}\text { Mean (herbaceous forest } \\
\text { pollen grains) }\end{array}$ & 26.5400 & & \\
\hline Tukey: & Diference & S & (p) \\
\hline $\begin{array}{l}\text { Means (arboreal } \\
\text { forest-grassland) }\end{array}$ & 22.1719 & 58.4142 & $<0.01$ \\
\hline $\begin{array}{l}\text { Means (arboreal } \\
\text { forest-herbaceous forest) }\end{array}$ & 26.5400 & 56.0297 & $<0.01$ \\
\hline $\begin{array}{l}\text { Means } \\
\text { (grassland-herbaceous forest) }\end{array}$ & 4.3681 & 13.8690 & $<0.01$ \\
\hline
\end{tabular}

Poaceae species has already been reported in South America. In Venezuela, larger pollen grains have already been reported to be related to the Bambusoideae and Pooideae subfamilies (SalgadoLabouriau and Rinaldi, 1990). However, in southern Brazil, we are able to differentiate at the level of tribes determining the Bambuseae pollen type. The Bambuseae pollen type is indicative of arboreal grasses and humid regions (Schmidt and and LonghiWagner, 2009).

TABLE 5 | Pearson correlation coefficient values showing the strength of relationship among the pore, annulus and size of the pollen grain.

\begin{tabular}{lccc}
\hline & $\begin{array}{c}\text { Pore- } \\
\text { annulus }\end{array}$ & $\begin{array}{c}\text { Pore-pollen } \\
\text { grain }\end{array}$ & $\begin{array}{c}\text { Annulus-pollen } \\
\text { grain }\end{array}$ \\
\hline$n=$ & 68 & 68 & 68 \\
$r($ Pearson $)=$ & 0.9257 & 0.8281 & 0.8565 \\
IC $95 \%=$ & $0.88-0.95$ & $0.73-0.89$ & $0.78-0.91$ \\
IC $99 \%=$ & $0.86-0.96$ & $0.70-0.91$ & $0.74-0.92$ \\
R2 $=$ & 0.8569 & 0.6858 & 0.7336 \\
$t=$ & 19.8779 & 12.0019 & 13.4797 \\
(p) $=$ & $<0.0001$ & $<0.0001$ & $<0.0001$
\end{tabular}

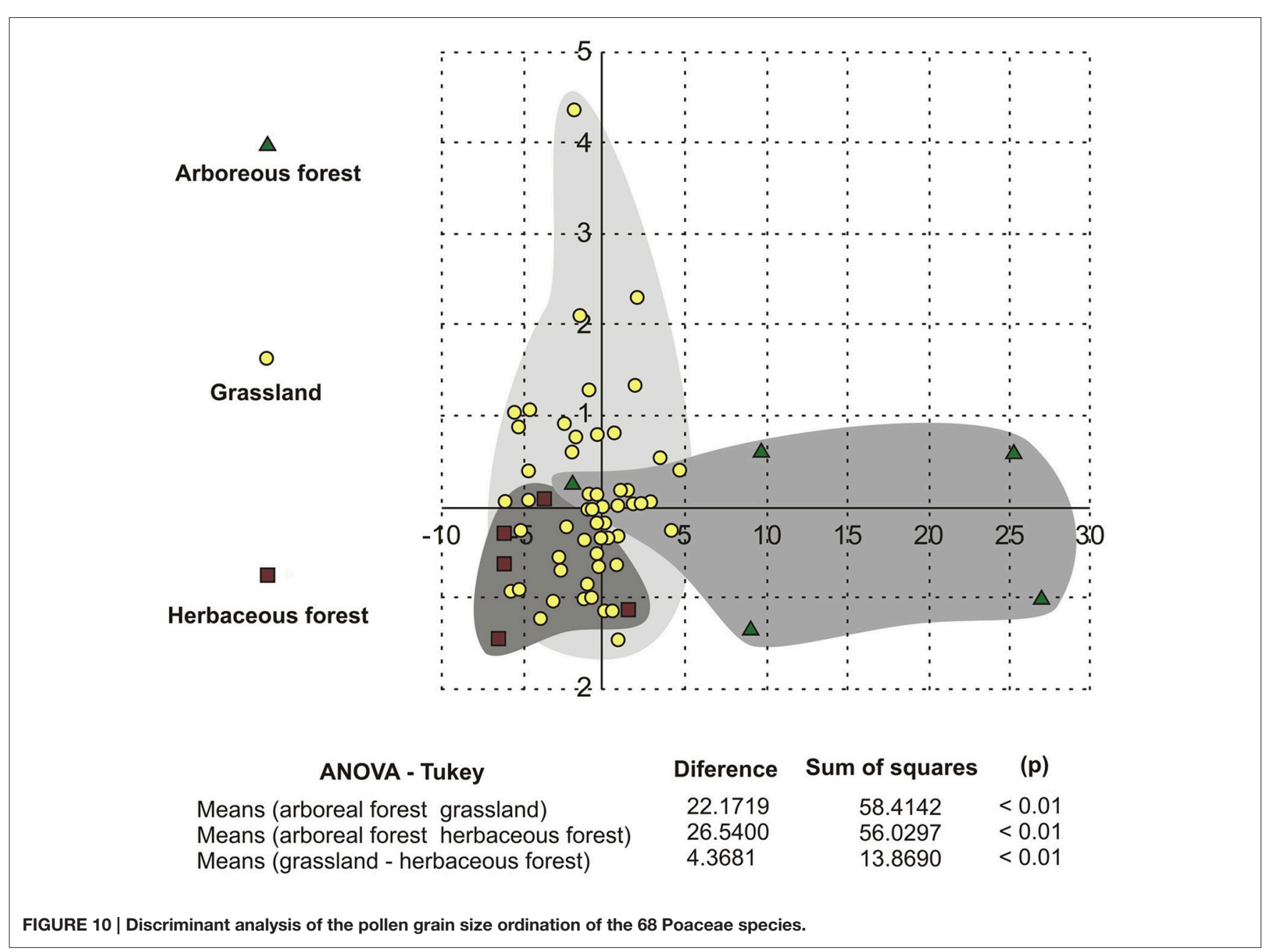




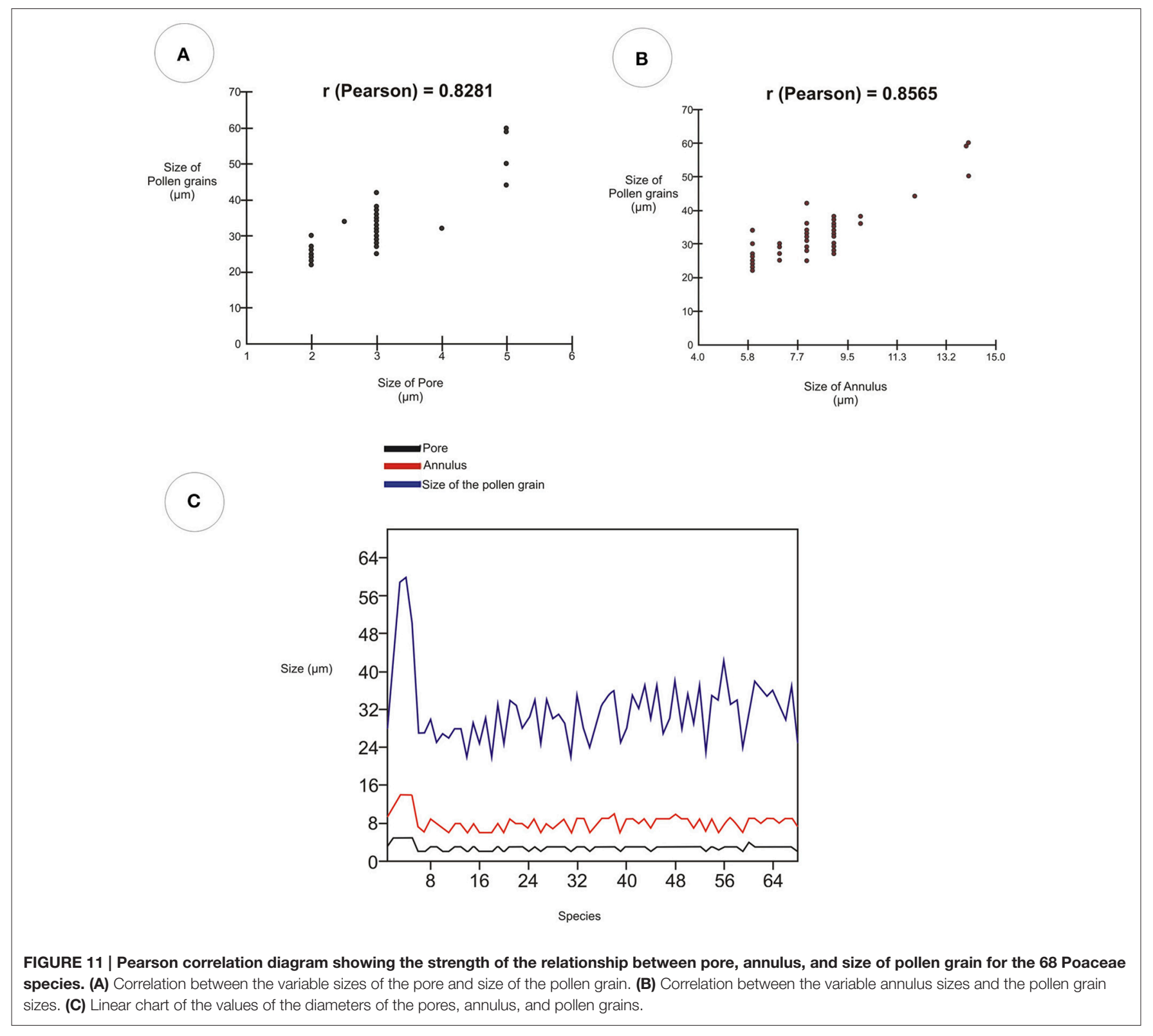

\section{Grassland Vegetation}

Pollen grains of grassland species are smaller than those of arboreous forest species and similar to those of herbaceous forest species. These results make it possible to identify the herbaceous pollen type. The smaller size of pollen grains in grassland species allows identification of the grassland pollen type. The small and medium sizes of pollen grains of grassland Poaceae species correspond to previous data relating to South American species (Heusser, 1971; Markgraf and D'Antoni, 1978; Salgado-Labouriau and Rinaldi, 1990; Melhem et al., 2003; Côrrea et al., 2005; Bauermann et al., 2013; Radaeski et al., $2014 \mathrm{a}, \mathrm{b}$ ) and species from other regions of the world (Joly et al., 2007; Jan et al., 2014; Morgado et al., 2015). The small size of pollen grains of grassland species can also be related to the type of dispersion involved, since grassland species produce more pollen than forest species (Radaeski and Bauermann, 2016).

\section{Exine}

Many studies have revealed differences in the exine sculpture of Poaceae pollen grains. Such differences are evident through the use of SEM, which allows adequate analysis of the surface (Köhler and Lange, 1979; Linder and Ferguson, 1985; Chaturvedi et al., 1994, 1998; Chaturvedi and Datta, 2001; Skvarla et al., 2003; Datta and Chaturvedi, 2004; Liu et al., 2004, 2005; Perveen, 2006; Kashikar and Kalkar, 2010; Ahmad et al., 2011; Dórea, 2011; Perveen and Qaiser, 2012; Mander et al., 2013, 2014; Nazir et al., 2013; Morgado et al., 2015; Needham et al., 2015; Mander and Punyasena, 2016). Light microscopy is used to study the fossil pollen of Quaternary sediments at smaller magnifications 
$(\times 400)$; SEM is not suitable for such study. Thus, data pollen measures seem to be more suitable to use in comparison with fossil pollen.

The thin exine of the Poaceae pollen grains is a remarkable characteristic, not exceeding $2 \mu \mathrm{m}$ in thickness and having equivalent sexine and nexine values. Because of this thin layer, many pollen grains-especially the larger ones-may display small changes in their spherical shape owing to the flattening of the pollen grain. This often provides the impression of pollen grains with prolate or oblate forms. However, these shapes are easily observed in crushed pollen grains, for when the non-deformed (used as parameters) pollen grains are examined,

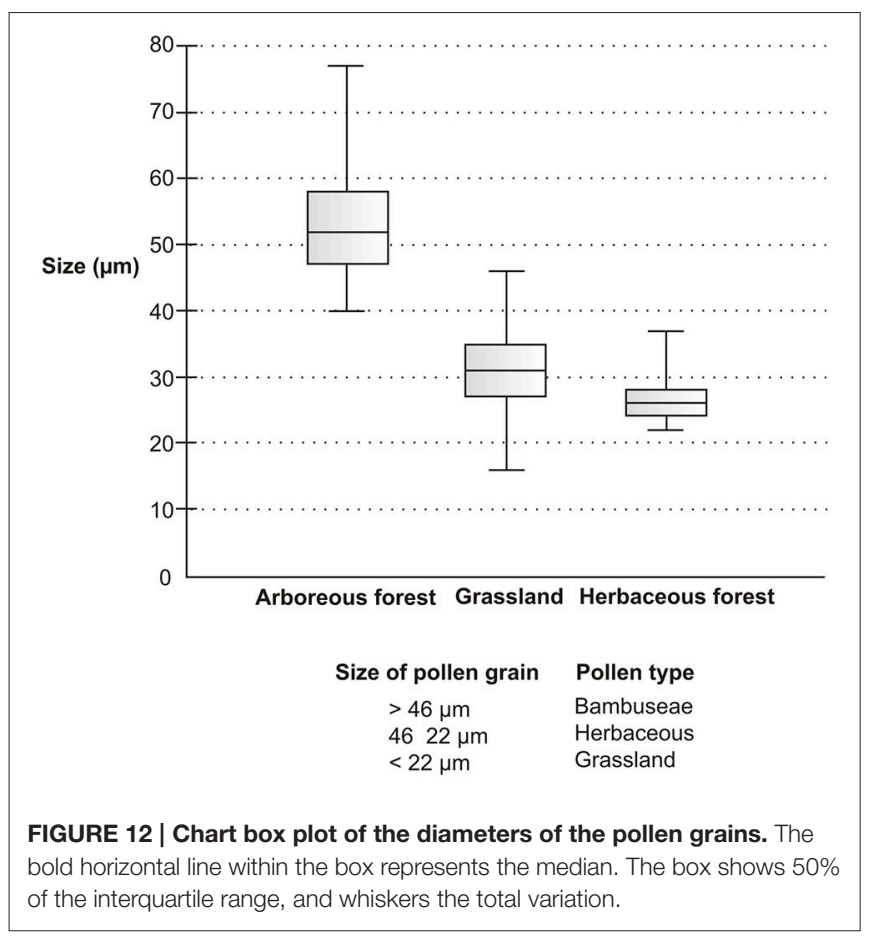

their spherical form-characteristic of the Poaceae family-is noted.

The surface of the exine of Poaceae pollen grains, when viewed by SEM, exhibits several variations among species (Dórea, 2011). However, when observed under light microscopy, the pollen surface exhibits a tectate exine with columellae and spinulose ornamentation. The variations in the surface of the exine observed by SEM cannot be observed by light microscopy. To identify the pollen grains (from pollen records) involving smaller increases, mainly occurring in Quaternary sediments, the ornamentation is often not observed. With a magnification of $\times 400$, much ornamentation of the studied taxa is not visible (Schüler and Behling, 2011a,b), for the ornamentation is often interpreted as psilate, scabrate, or microrreticulate surfaces. However, under higher (SEM) magnifications, the sculptured grain surfaces may be evident (Chaturvedi et al., 1998; Liu et al., 2004; Dórea, 2011; Mander et al., 2013).

\section{CONCLUSIONS}

Using a data set of 68 species, we found that types of vegetation can be distinguished according to Poaceae pollen grains. The size of pollen grains of arboreous forest Poaceae species differs from that of grassland and herbaceous forest species. The pollen grains of forest species of arboreal habit are larger than those of forest species of herbaceous habit. Through measurements and statistical analysis, we found that these Poaceae species exhibit variation in the size of pollen grains in species inhabiting arboreous forest, grassland, and herbaceous forest. Thus, three pollen types were identified: Bambuseae, herbaceous, and grassland pollen types.

Grassland and forest vegetation may be distinguished by examining Poaceae pollen grains from southern Brazil. Thus, the dynamics of the grassland and forest vegetation during the Pleistocene and Holocene periods can be demonstrated based on Poaceae pollen grains. Also, pollen characterization by vegetation

TABLE 6 | Pollen measures and establishment of pollen types.

Size of pollen Pollen type $\quad$ Species included
grain

$>46 \mu \mathrm{m} \quad$ Bambuseae

46-22 $\mu \mathrm{m} \quad$ Herbaceous

Chusquea juergensii, Colanthelia cingulata, Guadua trinii, Merostachys multiramea

Streptochaeta spicata, Lithachne pauciflora, Olyra latifolia, Parodiolyra micrantha, Pharus lappulaceus, Leersia sp., Luziola peruviana, Danthonia montana, Eleusine tristachya, Eragrostis bahiensis, Muhlenbergia schreberi, Tridens brasiliensis, Bouteloua megapotamica, Chloris canterae, Cynodon dactylon, Eustachys distichophylla, Gymnopogon spicatus, Microchloa indica, Spartina ciliata, Pappophorum philippianum, Aristida sp., Agrostis sp., Amphibromus quadridentulus, Calamagrostis viridiflavescens, Catapodium rigidum, Dactylis glomerata, Festuca fimbriata, Glyceria multiflora, Holcus lanatus, Poa bonariensis, Phalaris angusta, Polypogon elongatus, Bromus catharticus, Melica sp., Hordeum stenostachys, Piptochaetium montevidense, Stipa filifolia, Stipa melanosperma, Stipa papposa, Stipa setigera, Axonopus sp., Digitaria ciliares, Ichnanthus pallens, Panicum aquaticum, Paspalum notatum, Paspalum pauciciliatum, Paspalum urvillei, Setaria parviflora, Andropogon lateralis, Andropogon cf. lindmanii, Bothriochloa laguroides, Elionurus candidus, Imperata brasiliensis, Ischaemum minus, Schizachyrium microstachyum, Trachypogon filifolius

Eragrostis neesii, Leptochloa fusca, Sporobolus indicus, Tripogon spicatus, Aira elegans, Chascolytrum

$\begin{array}{ll}<22 \mu \mathrm{m} & \text { Grassland } \\ \text { subaristatum, Steinchisma hians, Arundinella hispida }\end{array}$ 


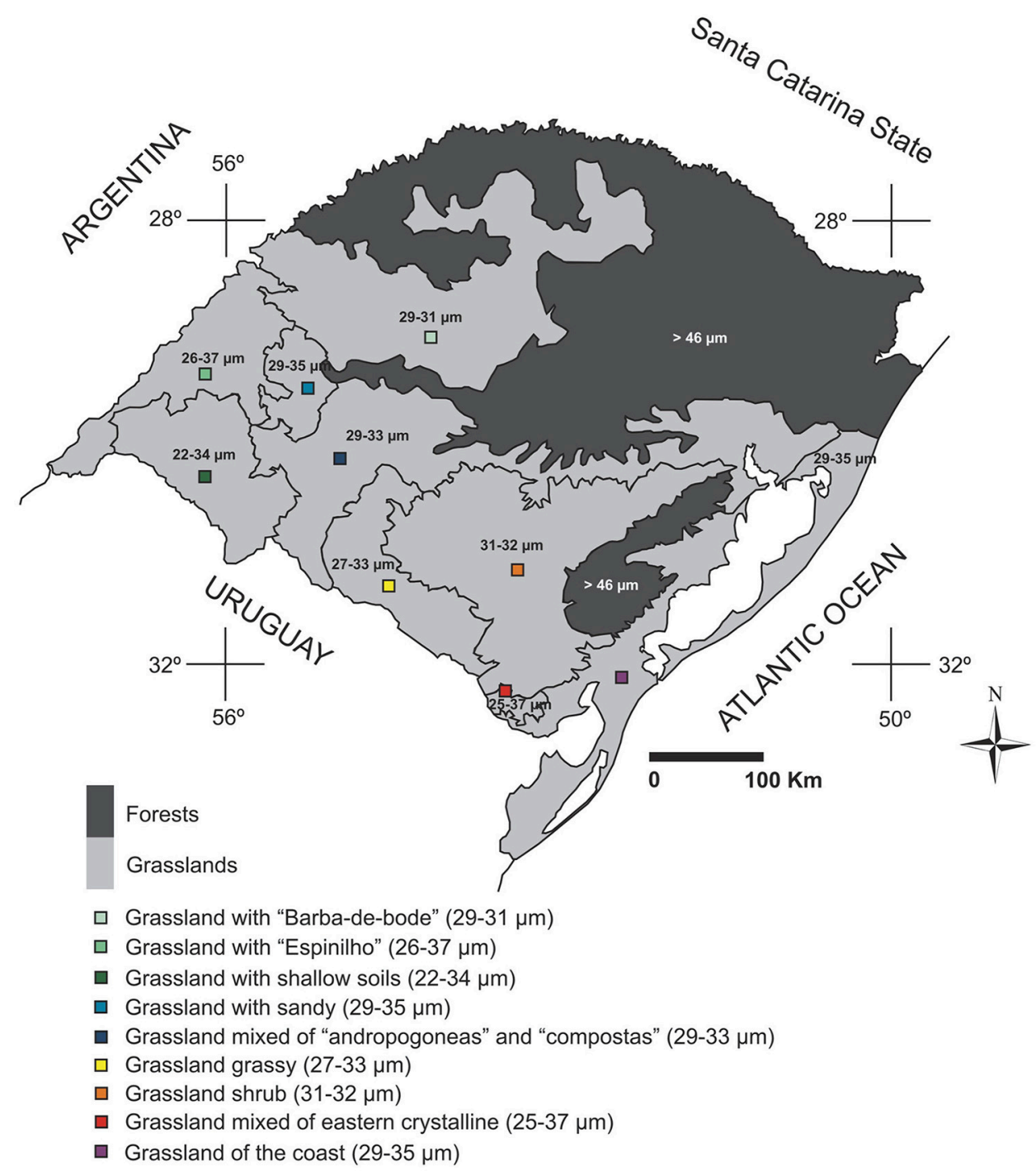

FIGURE 13 | Main changes in the average size of the Poaceae pollen grains in the different regions of Rio Grande do Sul, according to the vegetation physiognomies in RS (adapted from Hasenack et al., 2010).

is of great importance, since the pollen morphology of the grasslands and forests can be used as indicators of humid or dry environments, respectively.

By determining the size of pollen grains of 68 Poaceae species in RS, it was possible to indicate previously inaccessible information for ecological inferences concerning southern Brazil grasslands. Attaining better taxonomic resolution of both vegetation types allows new opportunities to expand the pollen records beyond the family level. Further research is needed on the pollen morphology of other native genera and species of the Poaceae family for RS. It is expected that further studies will allow greater differentiation between groups and improved knowledge of pollen morphology at a family level. The presented method is being applied to the development of pollen records for southern Brazil and may favor climactic reconstruction of past environments and an evaluation of the dynamics of Quaternary grassland Poaceae vegetation.

\section{AUTHOR CONTRIBUTIONS}

JR provided the images of the pollen grains and pollen measurements. JR, SB, AP structured and edited the manuscript during all phases. SB and AP supervised the project. JR and SB supported the paleoecological interpretations. JR and AP developed the botanical implications.

\section{ACKNOWLEDGMENTS}

This work is part of the M.Sc. dissertation of the first authors, sponsored by CAPES. Our appreciation goes to Dr. Angelo Alberto Schneider from UNIPAMPA, for the great help with the identification of botanical materials. Also, we want to thank the ICN herbarium. We thank Jim Kernaghan and Guy Barcellos for the linguistic revision. 


\section{REFERENCES}

Ahmad, F. A., Khan, M. A., Ahmad, M., Zafar, M., Khan, A., and Iqbal, Z. (2011). Palynological studies in tribe Chlorideae (Poaceae) from salt range of Pakistan. Afr. J. Biotechnol. 10, 8909-8913. doi: 10.5897/AJB10.2512

Barth, O. M., and Melhem, T. S. (1988). Glossário Ilustrado de Palinologia. Campinas: Editora da UNICAMP.

Bauermann, S. G., Macedo, R. B., Behling, H., Pillar, V., and Neves, P. C. P. (2008). Din $\beta$ micas vegetacionais, climáticas e do fogo com base em palinologia e análise multivariada no Quaternário Tardio no sul do Brasil. Rev. Bras. Paleontol. 11, 87-96. doi: 10.4072/rbp.2008.2.02

Bauermann, S. G., Radaeski, J. N., Evaldt, A. C. P., Queiroz, E. P., Mourelle, D., Prieto, A. R., et al. (2013). Pólen nas Angiospermas: Diversidade e Evolução. Canoas: Editora da ULBRA.

Behling, H., Pillar, V., and Bauermann, S. G. (2004). Late Quaternary Araucaria forest, grassland (Campos), fire and climate dynamics, inferred from a highresolution pollen record of Cambará do Sul in southern Brazil. Palaeogeogr. Palaeoclimatol. Palaeoecol. 203, 277-297. doi:10.1016/S0031-0182(03)00687-4

Boldrini, I. I. (2006). Biodiversidade dos Campos Sulinos. i Simpósio de Forrageiras e Produção Animal - Ênfase: Importßncia e Potencial Produtivo da Pastagem Nativa, Vol. 1. UFRGS, Departamento de Plantas Forrageiras e Agrometeorologia, 11-24.

Boldrini, I. I., and Longhi-Wagner, H. M. (2011). Poaceae no rio grande do sul: diversidade, importßncia na fitofisionomia e conservação. Ciência Ambiente 42, 71-92.

Chaturvedi, M., and Datta, K. (2001). Pollen morphology in Saccharurn L. (Poaceae) - wild and cultivated sugar cane species. Feddes Repertorium 112, 387-390. doi: 10.1002/fedr.4921120509

Chaturvedi, M., Datta, K., and Nair, P. K. K. (1998).Pollen morphology of Oryza (Poaceae). Grana 37, 79-86. doi: 10.1080/00173139809362647

Chaturvedi, M.,Yunus, D., and Datta, K. (1994). Pollen morphology of sorghum moench-sections eu-sorghum and para-sorghum. Grana 33, 117-123. doi: $10.1080 / 00173139409428987$

Côrrea, A. M. S., Guimarães, M. I. T. M., Cruz-Barros, M. A. V., and Begale, F. F. (2005). Flora polínica da reserva do parque estadual das fontes do ipiranga (São Paulo, Brasil). Hoehnea 32, 269-282. doi: 10.1590/S2236-890620110001 00009

Datta, K., and Chaturvedi, M. (2004). Pollen morphology of Basmati cultivars (Oryzasativa race Indica) - exine surface ultrastructure. Grana 43, 89-93. doi: $10.1080 / 00173130310017391$

Dórea, M. C. (2011). Morfologia polínica, Fenologia Reprodutiva e Biologia Floral de Espécies Florestais de Poaceae. Ph.D. thesis, Universidade Estadual de Feira de Santana.

Eva, H. D., Miranda, E. E., Di Bella, C. M., Gond, V., Huber, O., Sgrenzaroli, S., et al. (2002). A Vegetation Map of South America. Luxembourg: Join Research Centre. Office for Official Publications of the European Communities.

Erdtman, G. (1952).Pollen Morphology and Plant Taxonomy. Angiosperms. Stockholm: Almkvist \& Wiksell.

Filgueiras, T. S., Brochado, A. L., Nogueira, P. E., and Guala, I. I., G.F. (1994). Caminhamento - um método expedito para levantamentos florísticos quantitativos. Cadernos Geociê 12, 39-44.

Grass Phylogeny Working Group(GPWG). (2001). Phylogeny and subfamilial classification of the grasses (Poaceae).Ann. Missouri Bot. Garden 88, 373-457. doi: $10.2307 / 3298585$

Hasenack, H., Weber, E., Boldrini, I. I., and Trevisan, R. (2010). Mapa de Sistemas Ecológicos da Ecorregião das Savanas Uruguaias em escala 1:500.000 ou superior e Relatório Técnico descrevendo insumos e metodologia de elaboração do mapa de Sistemas Ecológicos. Relatório Técnico, The Nature Conservancy.

Heusser, C. J. (1971). Pollen and Spores of Chile. Tucson:The university of Arizona Press.

Jan, F., Schüler, L., and Behling, H. (2014). Trends of pollen grain size variation in C3 and C4 Poaceae species using pollen morphology for future assessment of grassland ecosystem dynamics. Grana 53, 1-17. doi: 10.1080/00173134.2014.966754

Joly, C., Barillé, L., Barreau, M., Mancheron, A., and Visset, L. (2007).Grain and annulus diameter as criteria for distinguishing pollen grains of cereals from wild grasses.Rev. Palaeobot. Palynol. 146, 221-233. doi: 10.1016/j.revpalbo.2007.04.003
Kashikar, N., and Kalkar, S. A. (2010). Pollen morphology of millets-exine surface ultrastructure. Asian J. Exp. Biol. Sci. Spl. 85-90. Available online at: http:// www.ajebs.com/special/SP-17.pdf

Katsiotis, A., and Forsberg, R. A. (1995). Pollen grain size in four ploidy levels of genus Avena. Euphytica 83, 103-108. doi: 10.1007/BF01678036

Köhler, E., and Lange, E. (1979). A contribution to distinguishing cereal from wild grass pollen grains by LM and SEM. Grana 18, 133-140. doi: 10.1080/00173137909424973

Linder, H. P., and Ferguson, I. K. (1985). On the pollen morphology and phylogeny of the Restionales and Poales. Grana 24, 65-76. doi: 10.1080/00173138509429917

Liu, Q., Zhao, N., and Hao, G. (2004). Pollen morphology of the Chloridoideae (Gramineae).Grana 43, 238-248. doi: 10.1080/00173130410000776

Liu, Q., Zhao, N., and Hao, G. (2005). Pollen morphology of Eustachys tenera (Chloridoideae, Gramineae). Pak. J. Bot. 37, 503-506. Available online at: http:// www.pakbs.org/pjbot/PDFs/37(3)/PJB37(3)503.pdf

Macedo, R. B., Cancelli, R. R., Bauermann, S. G., Neves, P. C. P., and Bordignon, S. A. L. (2007). Palinologia de níveis do Holoceno da Planície Costeira do Rio Grande do Sul (localidade de Passinhos), Brasil. Rev. Gaea Unisinos 3, 68-74. Available online at: http://revistas.unisinos.br/index.php/gaea/article/ view/5867/3053

Mander, L., Baker, S. J., Belcher, C. M., Haselhorst, D. S., Rodriguez, J., Thorn, J. L., et al. (2014). Accuracy and consistency of grass pollen identification by human analysts using electron micrographs of surface ornamentation.Applications in Plant Sciences 2, 1-11. doi: 10.3732/apps.1400031

Mander, L., Li, M., Mio, W., Fowlkes, C. C., and Punyasena, S. W. (2013). Classification of grass pollen through the quantitative analysis of surface ornamentation and texture. Proc. Biol. Sci. 280, 1-7. doi: $10.1098 /$ rspb.2013.1905

Mander, L., and Punyasena, S. W. (2016). Grass pollen surface ornamentation: a review of morphotypes and taxonomic utility. J. Micropalaeontol. 35, 121-124. doi: 10.1144/jmpaleo2015-025

Markgraf,V., and D'Antoni, H. (1978). Pollen flora of Argentina.Tucson: University of Arizona Press.

Medeanic, S., Cordazzo, C. V., and Lima, L.G. (2008). Diversidade Polínica de Plantas em Dunas no Extremo Sul do Brasil. Porto Alegre: Gravel.

Melhem, T. S., Cruz-Barros, M. A. V., Corrêa, M. A. S., Makino-Watanabe, H., Silvestre-Capelato, M. S. F., and Esteves, V. G. L. (2003). Variabilidade polínica em plantas de Campos do Jordão (São Paulo, Brasil). Bol. Inst. Bot. 16, 16-104.

Morgado, L. N., Gonçalves-Esteves, V., Resendes, R., and Ventura, M. A. M. (2015). Pollen morphology of Poaceae (Poales) in the Azores, Portugal.Grana 54, 282-293. doi: 10.1080/00173134.2015.1096301

Nakamura, A. T., Longhi-Wagner, H. M., and Scatena, V.L. (2010). Anther and pollen development in some species of Poaceae (Poales).Br. J. Biol. 70, 351-360. doi: 10.1590/S1519-69842010005000005

Nazir, A., Khan, M. A., Abbasi, A. M., Zahidullah. (2013). Palynological studies in Tribe Aveneae (Poaceae) from Potohar of Pakistan. Int. J. Sci. 10, 120-125.

Needham, I., Vorontsova, M. S., Banks, H., and Rudall, P. J. (2015). Pollen of Malagasy grasses as a potential tool for interpreting grassland palaeohistory. Grana 54, 247-262. doi: 10.1080/00173134.2015.1057220

Perveen, A. (2006). A contribution to the pollen morphology of family gramineae. World Appl. Sci. J. 1, 60-65.

Perveen, A., and Qaiser, M. (2012). Pollen flora of Pakistan - LXIX. Poaceae. Pak. J. Bot. 44, 747-756. Available online at: http://www.pakbs.org/pjbot/PDFs/44(2)/ 42.pdf

Punt, W., Hoen, P. P., Blackmore, S., Nilsson, S., and Le Thomas, A. (2007). Glossary of pollen and spore terminology. Rev. Palaeobot. Palynol. 143, 1-81. doi: 10.1016/j.revpalbo.2006.06.008

Radaeski, J. N., and Bauermann, S. G. (2016). Avaliação da produção polínica de Bromus catharticus Vahl e Guadua trinii(Nees) Nees ex Rupr. (Poaceae) para a interpretação de dados fósseis. Biotemas 29, 9-18.

Radaeski, J. N., Evaldt, A. C. P., and Bauermann, S. G. (2014a). Grãos de pólen de espécies ocorrentes na Unidade de Conservação Parque Estadual do Espinilho, Barra do Quarai, Rio Grande do Sul, Brasil. Pesqui. Bot. 65, 305-331. Available online at: http://www.anchietano.unisinos.br/publicacoes/botanica/ botanica65/BOTANICA\%2065.pdf

Radaeski, J. N., Evaldt, A. C. P., Bauermann, S. G., and Lima, G. L. (2014b). Diversidade de grãos de pólen e esporos dos Campos do sul do Brasil: descrições 
morfológicas e implicações paleoecológicas. Iheringia Série Bot. 69, 107-132. Available online at: http://www.fzb.rs.gov.br/upload/20140805153253ih69_1_ p107_132.pdf

Radaeski, J. N., Evaldt, A. C. P., Lima, G. L., and Bauermann, S. G. (2011). Grãos de pólen das formações campestres sul-brasileiras. Rev. Iniciação Científica 9, 59-67. Available online at: http://sites.ulbra.br/palinologia/graos-de-polendas-formacoes-campestres-sul-brasileiras.pdf

Roubik, D. W., and Moreno, J. E. (1991). Pollen and Spores of Barro Colorado Island. St. Louis, MO: Missouri Botanical Garden.

Salgado-Labouriau, M. L. (1973). Contribuição à Palinologia dos Cerrados. Rio de janeiro: Academia Brasileira de Ciências, 291.

Salgado-Labouriau, M. L. (2007). Critérios e Técnicas Para o Quaternário. São Paulo: Editora Blücher.

Salgado-Labouriau, M. L., and Rinaldi, M. (1990). Palynology of gramineae of the venezuelan mountains.Grana 29, 119-128. doi: 10.1080/00173139009427742

Schmidt, R., and Longhi-Wagner, H. M. (2009). A tribo Bambuseae (Poaceae, Bambusoideae) no Rio Grande do Sul, Brasil. Rev. Bras. Biociências 7, 71-128. Available online at: http://www.bambusc.org.br/wp-content/uploads/2009/05/ a-tribo-bambuseae-no-rs.pdf

Schüler, L., and Behling, H. (2011a). Characteristics of Poaceae pollen grains as a tool to assess palaeoecological grassland dynamics in South America. Veget. Hist. Archaeobot. 20, 97-108. doi: 10.1007/s00334-010-0264-0

Schüler, L., and Behling, H. (2011b). Poaceae pollen grain size as a tool to distinguish past grasslands in South America: a new methodological approach. Veget. Hist. Archaeobot. 20, 83-96. doi: 10.1007/s00334-0100265-z

Skvarla, J. J., Rowley, J. R., Hollowell, V. C., and Chissoe, W. F. (2003). AnnulusPore relationship in Gramineae (Poaceae) pollen: the pore margin of Pariana. Am. J. Bot. 90, 924-930. doi: 10.3732/ajb.90.6.924

Tedesco, S. B., Battistin, A., and Valls, J. F. M. (1999). Dißmetro dos grãos de pólen e tamanho dos estômatos em acessos diplóides e tetraplóides de Hemarthria altissima (Poiret) Stapf \& Hubbard (Gramineae). Santa Maria. Ciência Rural 29, 273-276. doi: 10.1590/S0103-84781999000 200014

Wilberger, T. P., Stranz, A., Paz, C., Boeni, B., Cancelli, R. R., Bauermann, S. B., et al. (2004). Flora do Setor Oriental do Planalto sul-rio-grandense. Guia de espécies vegetais. $1^{\mathrm{a}}$ Edn. São Leopoldo, ALPP.

Conflict of Interest Statement: The authors declare that the research was conducted in the absence of any commercial or financial relationships that could be construed as a potential conflict of interest.

Copyright (c) 2016 Radaeski, Bauermann and Pereira. This is an open-access article distributed under the terms of the Creative Commons Attribution License (CC BY). The use, distribution or reproduction in other forums is permitted, provided the original author(s) or licensor are credited and that the original publication in this journal is cited, in accordance with accepted academic practice. No use, distribution or reproduction is permitted which does not comply with these terms. 